[Radiocarbon, Vol, 23 No. 1, 1981, P 94-135]

\title{
UNIVERSITY OF SASKATCHEWAN RADIOCARBON DATES IX*
}

\section{A A RUTHERFORD, JUERGEN WITTENBERG, and ROSCOE WILMETH}

National Museums of Canada and Saskatchewan Research Council Radiocarbon Dating Laboratory

30 Campus Drive, Saskatoon, Saskatchewan

This series reports some of the measurements made since publication of the previous list ( $\mathrm{R}, 1979, \mathrm{v} 21, \mathrm{p} 48-94)$. Acetylene proportional gas counting methods essentially remain as described in Saskatchewan II $(\mathrm{R}, 1960, \mathrm{v} 2, \mathrm{p} 73)$. Bone dating is now carried out on soluble collagen extract (Longin, 1971). The laboratory is associated with the National Museum of Canada to provide radiocarbon dating service for Canadian archaeologists but commercial services are also available to others.

\section{SAMPLE DESGRIPTIONS}

ARCHAEOLOGIC SAMPLES

\section{Great Bear River site series, Northwest Territories}

Charcoal, wood, and humus from site (LgRk-1), S bank of Great Bear R, 400m below Great Bear Lake, Dist Mackenzie $\left(65^{\circ} 07^{\prime} 30^{\prime \prime} \mathrm{N}\right.$, $\left.123^{\circ} 32^{\prime} \mathrm{W}\right)$. Site, 11 to $12 \mathrm{~m}$ above river, characterized by Angostura points (MacNeish, 1955). Coll and subm 1952 by R S MacNeish, Natl Mus Canada (now at R S Peabody Foundation, Calgary).

\section{S-9. Charcoal, wood, and humus}

$4650 \pm 200$

From S50W45, Pit 2, 1m below surface.

\section{S-10. Charcoal}

$4800 \pm 200$

From S50W45, Pit 2, $50 \mathrm{~cm}$ below surface.

General Comment (RSM): dates too recent for Angostura. Denbigh-type burin in colln.

\section{Millard Creek site series, British Columbia}

Charcoal from site (DkSf-2A), $0.4 \mathrm{~km}$ from mouth of Millard Creek, $3.2 \mathrm{~km} \mathrm{~S}$ of Courtenay, Comox Dist, Vancouver I. $\left(49^{\circ} 40^{\prime} 00^{\prime \prime} \mathrm{N}, 124^{\circ}\right.$ $58^{\prime} 25^{\prime \prime} \mathrm{W}$ ) at ca $7.5 \mathrm{~m}$ asl. Extensive area of shell deposits covered with 2nd growth forest ca $50 \mathrm{yr}$ old. Assoc with bone awls, small shell disk beads, worked cannel coal (lignite), and considerable obsidian and rock crystal detritus. Food bones predominantly deer and salmon (Capes, 1977). Coll and subm 1960, 1973 by K Capes, Courtenay, British Columbia.

S-142. Charcoal, lower level

$$
8300 \pm 200
$$

From lower $30 \mathrm{~cm}$ of habitation-stained coniferous forest soil deposit.

* SRC Publication No. C-704-2-A-80 
S-944. Charcoal, lower level

$16,910 \pm 270$

From 76 to $81 \mathrm{~cm}$ below surface, bottom $1 / 3$ of unstratified test pit, assoc with bone whistle.

General Comment (KC): presence of Cascade point seems to place site in Old Cordilleran culture of Northwest, although biconically perforated cannel coal object is trait not hitherto assoc with tradition. S-142 compatible with ages of other sites of tradition; S-944 too early, probably coal contaminated.

\section{S-194. Pointed Mountain site, Northwest Territories $2270 \pm 80$}

Charcoal from site (JcRx-3), $32 \mathrm{~km} \mathrm{~N}$ of Fort Liard, $4 \mathrm{~km} \mathrm{~N}$ of Fisherman Lake, Dist Mackenzie $\left(60^{\circ} 20^{\prime} \mathrm{N}, 123^{\circ} 30^{\prime} \mathrm{W}\right)$. From Sq S75E65, depth $35 \mathrm{~cm}$, Fireplace No. 1, ca 5000 to 8000 yr (MacNeish, 1954). Coll and subm 1962 by R S MacNeish. Comment (RSM): date too recent.

\section{S-577. Mann site, Saskatchewan}

$4930 \pm 100$

Charcoal from cone-shaped hearth, Mann site, N bank S Saskatchewan $\mathrm{R}\left(50^{\circ} 58^{\prime} \mathrm{N}, 109^{\circ} 26^{\prime} \mathrm{W}\right)$. Hearth $0.76 \mathrm{~m}$ deep, $3 \mathrm{~m}$ below surface contained butchered bison bone, stone flakes but no diagnostic artifacts. Coll and subm 1970 by W Pendree, Eston. Comment (AAR): probably early Oxbow site.

\section{S-651. Eriksdale burial, Manitoba $\quad 3360 \pm 100$}

Human tibia (UM-A-LABl) from burial near Eriksdale $\left(50^{\circ} 54^{\prime}\right.$ $\mathrm{N}, 97^{\circ} 50^{\prime} \mathrm{W}$ ). Small Pelican Lake point embedded in femur with evidence of healed wound. Coll 1971 by J Maas; subm 1972 by J Maas and E L Syms, Brandon Univ. Comment (ELS): date appears too old.

\section{S-652. Lord site, Manitoba}

$1170 \pm 90$

Bone (UM-A-LAB2) from Late Woodland, Blackduck component site along Red R, St Norbert $\left(49^{\circ} 45^{\prime} \mathrm{N}, 97^{\circ} 09^{\prime} \mathrm{W}\right)$. Coll and subm 1972 by J Maas and E L Syms. Comment (ELS): acceptable for early Blackduck (Syms, 1976b; 1977).

\section{S-675. Skoglund's Landing site, British Columbia $2510 \pm 90$}

Charcoal from sand and fire-cracked rock matrix (NMC-434), site (FIUa-1), $5.8 \mathrm{~km} \mathrm{~S}$ of Masset on E shore of Masset Sound, Graham I. $\left(53^{\circ} 57^{\prime} \mathrm{N}, 132^{\circ} 07^{\prime} \mathrm{W}\right)$. Two component site ca $13.7 \mathrm{~m}$ above max high tide. From N 0.45 to $10.88 \mathrm{~m}$, E 0.7 to $1.05 \mathrm{~m}$, upper occupation level, ca $1.12 \mathrm{~m}$ below surface. Assoc with 1500 flaked basalt artifacts including primarily retouched flakes and bipolarly percussed forms. Coll and subm 1969 by K R Fladmark, Univ Calgary (now Simon Fraser Univ). Comment (KRF): acceptable date.

\section{S-676. Bluejacket site, British Columbia}

$4160 \pm 120$

Charcoal (NMC-436) from site (F1Ua-4), $2.4 \mathrm{~km} \mathrm{~S}$ of Masset on E shore of Masset Sound, S of Skaga Point $\left(54^{\circ} 00^{\prime} 00^{\prime \prime} \mathrm{N}, 132^{\circ} 07^{\prime} 45^{\prime \prime} \mathrm{W}\right)$. From Test Pit 1, N 2m E 0.6m, Level 7, $1.25 \mathrm{~m}$ below surface, in matrix of clam shells, dark soil, and bone fragments. Extensive shell midden deposits 0.3 to $2.4 \mathrm{~m}$ depth, ca $13.7 \mathrm{~m}$ asl. Assemblage: retouched basalt 
flakes, large crude pebble choppers, boulder spall scrapers, various pecked and ground-stone artifacts, abrasive stones, ground slate, and worked bone. Latter appear to correlate with middle to late periods of Prince Rupert Harbour sequence (MacDonald, 1969). Should date major component late portion of Queen Charlotte sequence ca 2000 to 4000 yr. Coll and subm 1970 by K R Fladmark. Comment (KRF): acceptable date.

\section{S-677. Kasta site, British Columbia}

$6010 \pm 100$

Wood charcoal fragments (NMG-438) from site (FgTw-4), 482m inland from Copper Bay, $12.1 \mathrm{~km} \mathrm{~S}$ of Sandspit, Moresby I., Queen Charlotte Is. $\left(53^{\circ} 09^{\prime} 00^{\prime \prime} \mathrm{N}, 131^{\circ} 48^{\prime} 10^{\prime \prime} \mathrm{W}\right)$. From Pit A, Level 2, $0.6 \mathrm{~m}$ below surface, latest undisturbed occupation. Stratified site, at least 9 occupation levels, no marked difference between levels in artifact assemblage, includes microblades, microblade cores, tool flakes, prepared flake cores, pebble choppers, abrasive stones similar to Lawn Point site. Coll 1970 by B Thomas; subm 1970 by K R Fladmark. Comment (KRF): acceptable date, falls near end of Moresby tradition.

\section{Lawn Point site series, British Columbia}

Charcoal from site (FiTx-3), 24.1km $\mathrm{N}$ of Skidegate Mission, E coast of Graham I., Queen Charlotte Is. (53 $25^{\prime} 45^{\prime \prime} \mathrm{N}, 131^{\circ} 55^{\prime} 00^{\prime \prime} \mathrm{W}$ ). Multicomponent, upper levels sparse lithic assemblage including large pebble choppers and tool flakes assoc with two rock-ringed hearths. Two lower levels contained microblades, microblade cores, large prepared flake cores, specialized tool flakes, pebble choppers, hammerstones, and one abrasive stone. Coll 1970 by J Hunston and K Wildfong; subm 1970 by K R Fladmark.

S-678. Lawn Point site, upper level

$2010 \pm 60$

Charcoal (NMC-439) from N $1.9 \mathrm{~m}$ E $0.95 \mathrm{~m}, 0.66 \mathrm{~m}$ below surface, in brown sandy soil, light brown sand above, compact dark brown clayey soil below.

S-679. Lawn Point site, Level 12

$7400 \pm 140$

Charcoal (NMC-441) from N 2.2m E $1.83 \mathrm{~m}, 2.68 \mathrm{~m}$ below surface, in brown medium coarse sand, fire-cracked rock and assoc artifacts.

General Comment (KRF): acceptable dates.

S-686. Feland site, Manitoba

$500 \pm 130$

Mammal bones found near Antler R, SW Manitoba $\left(49^{\circ} 00^{\prime} \mathrm{N}\right.$, $\left.101^{\circ} 19^{\prime} \mathrm{W}\right)$. Contained Late Woodland component possibly related to Devils Lake-Sourisford burial complex (Syms, 1977; 1978). Coll 1971 and subm 1972 by E L Syms. Comment (ELS): represents terminal date range.

\section{Brockinton site series, Manitoba}

Bison bone from E bank of Souris R, S of Melita $\left(49^{\circ} 12^{\prime} \mathrm{N}, 101^{\circ}\right.$ 02' W). Stratified multicomponent Late Woodland site (Syms, 1971; 1972). Coll 1971 and subm 1972 by E L. Syms. 
S-687a. Occupation 1 (earliest)

$$
1110 \pm 80
$$

S-687b. Rerun

$1320 \pm 100$

S-688. Occupation 2

$1430 \pm 80$

S-689. Occupation 3

$350 \pm 130$

General Comment (ELS): part of series of 9 dates from 3 labs; in 2 cases samples divided for alternate fraction dating. S-687 dates generally agree with apatite date $1260 \pm 130$ BP (GaK-3805a: unpub) but different from acid residue dates $630 \pm 300 \mathrm{BP}$ and $510 \pm 80 \mathrm{BP}$ (GaK-3805b and -3806: unpub) from same occupation. S-688 unacceptable for strata position. S-689 agrees with alkali insoluble fraction date $290 \pm 120$ вP (A1206a: unpub) but not humate fraction $1240 \pm 65$ BP (A-1206b: unpub) (Long and Tamplin, 1977).

S-690. Stendall site, Manitoba

$850 \pm 80$

Bison bone from Pipestone Creek, SW Manitoba $\left(49^{\circ} 48^{\prime} \mathrm{N}, 101^{\circ}\right.$ $\left.20^{\prime} \mathrm{W}\right)$. Multicomponent Late Woodland containing Blackduck and other undefined materials. Coll 1972 by W M Hlady; subm 1972 by E L Syms. Comment (ELS): date younger than $965 \pm 70$ вP (S-786; R, 1979, v 21, p 63) (Syms, 1977) for Level 3.

\section{Snyder Dam site series, Manitoba}

Bone and charcoal from site (DhMg-37), along Souris R, SW Manitoba $\left(49^{\circ} 10^{\prime} \mathrm{N}, 101^{\circ} \mathrm{W}\right)$. Stratigraphically separated components yielding late Middle Woodland and Late Woodland ceramics (Syms, 1979). Coll 1971 by K Williams; subm 1973 by E L Syms.

\section{S-739. Bone (73-1) from hearth, Occupation $1 \quad 930 \pm 70$ \\ S.741. Charcoal (73-3) from hearth, Occupation 1 \\ $1010 \pm 60$}

S.740. Charcoal (73-2) from hearth, Occupation $2670 \pm 70$ General Comment (ELS): bone collagen and charcoal dates comparable ca 1 d for Occupation 1, previous bone date $1120 \pm 75$ вP (S-683: R, 1975, v 17, p 344).

\section{S-743. Reston burial site, Manitoba}

$670 \pm 180$

Human long bone fragments discovered by gravel pit operations (Braddell, Minty, and Tamplin, 1970) near Reston $\left(49^{\circ} 40^{\prime} \mathrm{N}, 101^{\circ} 09^{\prime}\right.$ W). Materials assigned to Late Woodland, Devils Lake Sourisford burial complex (Syms, 1976a; 1977; 1978). Coll 1969 by D Braddell; subm 1973 by E L Syms.

\section{Nunguvik Site Series 1, Northwest Territories}

Plant material and bone from site (PgHb-1), S of Low Point, W coast of Navy Board Inlet, Baffin I. ( $\left.73^{\circ} 01^{\prime} 30^{\prime \prime} \mathrm{N}, 80^{\circ} 38^{\prime} \mathrm{W}\right)$. Important $\mathrm{N}$ Baffin I. site, occupied most of Dorset and Thule periods, more than 80 houses, dated 1290 \pm 120 (Gak-2339: unpub). Recent excavation 
collns yielded not previously known wooden artifacts assoc with plant material. Coll 1971, 1973 and subm 1973 by Fr C Mary-Rousseliere, Catholic Mission, Pond Inlet.

S-766. Nunguvik site, House 71

$860 \pm 70$

Plant material (NMC-510) above flagstones on S side of Dorset House 71. Should date main occupation period ca $1200 \mathrm{yr}$.

S-767. Nunguvik site, House 71

$2280 \pm 90$

Bone (NMC-511) from deep pit in house, under flagstones. Should date earliest occupation or antedate house.

S-845. Nunguvik site, House 76

$1310 \pm 90$

Plants (mostly Cassiope tetragona) (NMC-649), from thick layer of plant material (possible mattress), ca $25 \mathrm{~cm}$ below surface in Dorset house, ca $5.5 \mathrm{~m}$ asl. Artifacts indicate early Middle Dorset period ca $1900 \mathrm{yr}$.

S-846. Nunguvik site, House 73

$1490 \pm 70$

Plants (mostly Cassiope tetragona) (NMC-650), Sq 10, from $0.75 \mathrm{~m}$ to $1.7 \mathrm{~m}$ above high tide. From thick layer in NE corner of partially excavated house, 20 to $25 \mathrm{~cm}$ below surface, cultural use uncertain. Dorset house, but semi-subterranean entrance passage suggests Thule influence, ca $800 \mathrm{yr}$.

\section{S-847. Nunguvik site, House 82}

$1690 \pm 150$

Caribou bone (NMC-651), 2.4m asl, E of House 76. From lowest of 3 occupation levels, 35 to $40 \mathrm{~cm}$ below surface. Two harpoon heads suggest early Dorset period ca 2200 yr. If confirmed, would show sea level less than $2 \mathrm{~m}$ above present level, significantly lower than most estimates for region.

\section{S-848. Nunguvik site, House 71}

$1590 \pm 100$

Caribou bone (NMC-652) from NNE corner of house, at base of wall, 40 to $45 \mathrm{~cm}$ below surface, appears to antedate house. Artifacts suggest earlier occupation, ca $1500 \mathrm{yr}$, than previous burnt bone data $1290 \pm 120$ вP (Gak-2339: unpub).

S-849. Nunguvik site, House 76

$1520 \pm 70$

Caribou bone (NMC-653) from lower level of house, $40 \mathrm{~cm}$ below surface. Should date earliest occupation before house construction, ca $2300 \mathrm{yr}$.

S-879. Nunguvik site, House 73

$1320 \pm 90$

Caribou bone (NMC-655) from lower level of entrance passage, late Dorset house, 10 to $25 \mathrm{~cm}$ below flagstone and 30 to $35 \mathrm{~cm}$ below surface, less than $1 \mathrm{~m}$ above high tide. Should date first occupation of shore when sea near present level and antedate House 73 . 
S-880. Nunguvik site, House 46

$1880 \pm 90$

Caribou bone (NMC-656) from early Dorset house, on 12m terrace, 20 to $35 \mathrm{~cm}$ below surface. Should be more reliable than previous mixedbone date 2655 + 80 вP (S-672: R, 1975, v 17, p 343).

S-882. Nunguvik site, House 52

$850 \pm 100$

Caribou bone (NMC-658) from early Thule house, on $12 \mathrm{~m}$ terrace but $200 \mathrm{~m}$ from other Thule houses. Bone date $1100 \pm 135$ yr (S-673: R, 1975 , v 17, p 343) corrected as AD 1270 agrees with plant material corrected dates AD 1210 and 1235 (S-477 and -516: R, 1973, v 15, p 202-203) for earlier Thule House 42. Two occupations probably separated by $100 \mathrm{yr}$.

S-883. Nunguvik site, House 76

$1530 \pm 100$

Plants (mostly Cassiope tetragona) (NMC-659) from plant material layer ca $35 \mathrm{~cm}$ below surface, Sq 11,5 to $6 \mathrm{~m}$ asl. Should date early occupation and be similar to S-845, ca 1900 to $2000 \mathrm{yr}$.

General Comment (GM-R): previous early Dorset date on marine animal bones (S-672: R, 1975, v 17, p 343) considered better House 46 date than S-880, ca 270 to 390 BC period. S-847 too recent for House 82 assoc with Dorset harpoon artifacts. S-883 and -849 acceptable for House 76 occupation levels. S-846 and -879 , House 73 . dates same apparent age range as House 76 , though typologically, 76 seems older. House 73 surprisingly old for same relative shore position (less than $1.5 \mathrm{~m}$ asl) as more recent neighbor House 71 . S-767 corrected as AD 70 indicates camping near present sea level at beginning of Christian era prior to House 71 construction. Supported by wall base date S-848, corrected as AD 440. S-766 at AD 1095 probably latest House 71 occupation, almost identical to early Thule house 42 (S-477: R, 1973, v 15, p 202) would suggest simultaneous or close sequel to Dorset and Thule habitations. Thule House 52 slightly early but acceptable compared to previous dates AD 1090 and 1235 (S-477 and -516: R, 1973, v 15, p 202-203). Marine animal bone date corrected as AD 1250 (S-673: R, 1975, v 17, p 343) more satisfactory.

\section{Migod site series, Northwest Territories}

Charcoal from site (KkLn-4) on E bank Dubawnt R at effluence of Grant Lake, Dist Keewatin $\left(63^{\circ} 43^{\prime} 00^{\prime \prime} \mathrm{N}, 100^{\circ} 26^{\prime} 50^{\prime \prime}\right.$ W). Multicomponent with late Shield Archaic and Agate Basin components. Coll and subm 1973 by J V Wright, Natl Mus Canada.

\section{S-812. Migod site, Stratum VI}

$4790 \pm 130$

Charcoal (NMC-670) from Trench 1, 66cm depth. Will date late Shield Archaic component in Keewatin and check minimal Shield Archaic date $1075 \pm 90$ BC (S-506: R, 1973, v 15, p 205) from Aberdeen Lake site (LdL1-2). Ca 3500 to 4000 yr. 
S-834. Migod site, Stratum VIB $7930 \pm 500$

Charcoal (NMC-671) from Trench 1, $78.7 \mathrm{~cm}$ depth. Stratum between late Shield Archaic and Agate Basin components. May represent early Shield Archaic component, no diagnostic artifacts. Ca 4000 to 7500 yr.

S-813. Migod site, Stratum VII $5550 \pm 120$

Charcoal (NMC-672) from Trench 1, 86.3cm depth. Agate Basin component and check on Grant Lake site (KhLn-2) dates.

S-1052. Migod site, Stratum VII

$6010 \pm 130$ $9000 \mathrm{yr}$.

Charcoal (NMC-803) from Trench 1, ca $86.4 \mathrm{~cm}$ depth. Ca 8500 to General Comment (JVW): S-812 basically agrees with late Shield Archaic components on Thelon R, Dist Mackenzie by B C Gordon. Ranges of S-813 and -1052 tend to reinforce one another, seriously questioning Agate Basin assignment to Stratum VII, but does not explain older age anomaly of S-834 stratigraphically above Stratum VII.

\section{S-912. Bracken Cairn, Saskatchewan}

$2470 \pm 90$

Human bone fragments from burial, $0.8 \mathrm{~km} \mathrm{~S}$ of Frenchman $\mathrm{R}$ near Bracken $\left(49^{\circ} 20^{\prime} \mathrm{N}, 108^{\circ} 18^{\prime} \mathrm{W}\right)$. Ocher burial, male, female, and infant, 0.9 to $1.2 \mathrm{~m}$ below surface, on prominent knoll, covered by large stone cairn. Assoc artifacts discussed elsewhere (King, 1961). Coll 1948, 1956 by L Wright; subm 1974 by W Pendree. Comment (AAR): confirms Pelican Lake affiliation suggested by assoc projectile points.

\section{Richards Village site series, Manitoba}

Bone from site near Pembina $\mathrm{R}$ between Turtle Mt and Pembina valley, $\mathrm{S}$ central Manitoba $\left(49^{\circ} 03^{\prime} \mathrm{N}, 99^{\circ} 42^{\prime} \mathrm{W}\right)$. Early Sonota component and later Blackduck component site. Coll 1973 by E L Syms and 1975 by C Richards; subm 1974 and 1977 by E L Syms.

\section{S-913. Bone (Br-74-1)}

$920 \pm 60$

Upper Blackduck occupation.

\section{S-1338. Bone (Br-77-1)}

Level 4 to 5,16 to $20 \mathrm{~cm}$ below surface, assoc with Sonota materials. General Comment (ELS): dates acceptable.

\section{S-921. Hahanudan site, Alaska}

Calcined bone, primarily mammal (NMC-713) from site (RkIk-4), Hahanudan Lake, near Huslia village, Koyukuk R region, W interior Alaska $\left(65^{\circ} 41^{\prime} 30^{\prime \prime} \mathrm{N}, 153^{\circ} 20^{\prime} 00^{\prime \prime} \mathrm{W}\right)$. From bone scatter over small area, generally ca $50 \mathrm{~cm}$ below turf. Artifact assemblage ceramics, delicate end blades suggestive of Norton culture and others not so distinctively placed. Suggests significant inland penetration of Norton culture or influence. Ca 1500 to $2500 \mathrm{yr}$. Coll and subm 1971 by D W Clark, Natl Mus Canada. Comment (DWC): date may indicate younger en- 
campment than end blades. Metal pan recovered off site end and group of undated cache pits supports habitation at various times. Large error margin AD 730 to 1640 limits usefulness, tentative assoc with Nortonderivative artifacts (Clark, 1977).

\section{Diana 4A site series, Northwest Territories}

Charcoal and carbonized fat from Dorset site (JfE1-4A), $7 \mathrm{~m}$ asl, $\mathrm{S}$ Diana I. $\left(60^{\circ} 55^{\prime} 50^{\prime \prime} \mathrm{N}, 69^{\circ} 57^{\prime} \mathrm{W}\right)$. Coll 1973 and subm 1974 by $\mathrm{P}$ Plumet, Univ Quebec, Montreal.

\section{S-930. Diana 4A site, black humus}

$760 \pm 100$

Charcoal (NMC-72I) under gravel slipped from wall. May date occupation or previous occupation assoc with midden between Houses $\mathrm{A}, \mathrm{B}$, and $\mathrm{C}$.

\section{S-932. Diana 4A site, Structure $C$}

$2180 \pm 70$

Carbonized fat (NMC-723) from NN43, N end of midden of Structure $\mathrm{C}$.

\section{S-933. Diana 4A site, Structure C}

$1890 \pm 110$

Charcoal (NMC-724) from NN43, N midden of Structure C.

General Comment (PP): S-930 inside House A seems to precede occupation dated at AD $1480 \pm 90$ (Gif-3002: unpub). Date appears to relate to dump of D1A-4C into which D1A-4A was dug. Carbonized fat, S-932, thoroughly mixed with charcoal, S-933. Date difference confirms aging attributed to sea mammal fat. Dates suggest dump in which D1A-4A constructed corresponds to many occupations between dates obtained for D1A 25 (Gif-2969: unpub) and various parts of D1A I (Lv-468-471: R, 1971, v 13, p 49) and 560 (Gif-1954-1957, -1352, R, 1974, v 16, p 47; Gif-2967-2970, unpub; Gif-3002-3004, unpub). S-933 may represent average charcoal age over 20 to $40 \mathrm{~cm}$ depth, same sector as $30 \mathrm{~cm}$ depth charcoal previously dated AD $870 \pm 100$ (Gif-3003: unpub). Dates suggest Structure D1A-4A contemporaneous with Diana Bay Sites D1A 25 (JfEm-5) and D1A 1 (JfE1-1).

\section{S-931. Cordeau site, Northwest Territories $\quad 1420 \pm 100$}

Carbonized wood (NMC-722) from site (IfEl-1), S Diana I. $\left(60^{\circ} 56^{\prime}\right.$ $\left.\mathrm{N}, 69^{\circ} 57^{\prime} \mathrm{W}\right)$. From Sq 3I, in deposit immediately below humus layer, possibly from House A. Caribou bone and Dorset artifacts. Coll 1973; subm 1974 by P Plumet. Comment (PP): sample from $2 \mathrm{~m}$ NW of Long House D1A 1-A, carbonized fat dated $1170 \pm 100$ yr BP (Gif-2967: unpub). Deposit contemporaneous with Houses D1A 1-E and F (Lv-469-471: R, 1971, v 13, p 49; Gif-1352: R, 1974, v 16, p 47; Gif-2968: unpub) located on other side of small lake ca $30 \mathrm{~cm} \mathrm{~W}$ of D1A 1-A. Artifacts of polished schist analogous to those of DIA 1-F, also assoc with caribou bones.

\section{S-975. Hahanudan 2-House site, Alaska}

$290 \pm 100$

Charcoal and carbonized wood (NMC-747) from S side Hahanudan Lake, Melozitna quad, W interior Alaska (65 43' $30^{\prime \prime} \mathrm{N}, 155^{\circ} 32^{\prime} 30^{\prime \prime}$ 
W). From 6.7 to $7.2 \mathrm{~m}$ asl Cache Pit A, one of several poles that probably supported birchbark cover. Assoc with Ipiutak-related house but could be later Athapaskan. Ca AD 600 or much more recent. Coll 1971 and subm 1975 by D W Clark. Comment (DWG): date indicates cache pit and houses, ca $3 \mathrm{~m}$ apart, unrelated occupations. Cache pits probably constructed by late prehistoric antecedents of Koyukuk branch of present Koyukon Athapaskans (Clark, 1977).

\section{Migod site series, Northwest Territories}

Charcoal and charcoal mixed with sand and clay from site (KkLn4), at Grant Lake, Dubawnt R, Dist Keewatin $\left(63^{\circ} 43^{\prime} 00^{\prime \prime} \mathrm{N}, 100^{\circ} 26^{\prime}\right.$ $50^{\prime \prime} \mathrm{W}$ ). Site contains nine levels and sublevels. Uppermost (Levels 1, 2a, 2b) Taltheilei Chipawyan tradition; middle sec scattered Arctic Small Tool tradition (Levels 3a, 3b) and bottom Shield Archaic (Levels 4a, 4b, 4c). Coll 1974 by B Gordon, J Sproull, P Kay, C Arnold, D Morrison, and M Gordon; subm 1975 by B Gordon, Natl Mus Canada.

S-977. Migod site, Level 2a $1630 \pm 130$ to 800 .

Charcoal in sand (NMC-749), 12N6E. Middle Taltheilei ca AD 400

S-978. Migod site, Level 3

$2790 \pm 90$

Charcoal and charcoal in clay (NMC-750), combined sample. Arctic Small Tool tradition ca 600 to 1200 BC.

S-979. Migod site, Level $4 a$

$4770 \pm 170$

Charcoal in sand (NMC-751), 14N6E. Late Shield Archaic ca 2000 to $4000 \mathrm{BC}$.

S-980. Migod site, Level $4 a$

$4770 \pm 170$ 4000 BC.

Charcoal in sand (NMC-752), 6N4E. Late Shield Archaic ca 2000 to

S-1005. Migod site, Level $4 b$

$4950 \pm 90$

Charcoal in sand (NMC-753), 14N6E. Middle Shield Archaic ca 3000 to 5000 BC.

S-981. Migod site, Level $4 b$

$\mathbf{5 0 7 0} \pm \mathbf{8 0}$ 5000 BC.

Charcoal (NMC-754), 12N4E. Middle Shield Archaic ca 3000 to

S-1007. Migod site, Level 1

Modern yr BP.

Charcoal in sand (NMC-756), 2N4E. Late Taltheilei ca 200 to 500

S-1008. Migod site, Level 2a

$1560 \pm 80$ to 800 .

Charcoal in sand (NMC-757), 10N4E. Middle Taltheilei ca AD 400 
S-1009. Migod site, Level 2 a

$1050 \pm 100$ to 800 .

Charcoal in sand (NMC-758), 12N4E. Middle Taltheilei ca AD 400

S-1010. Migod site, Level 4

$1420 \pm 70$

Charcoal in sand (NMC-759), 8N2E. General Shield Archaic ca 2000 to 5000 вс.

S-1020. Migod site, Level 1

$1920 \pm 80$ 800 .

Charcoal in sand (NMG-761), 10N4E. Late Taltheilei ca AD 400 to

S-1021. Migod site, Level $1 \mathrm{~b}$

$1010 \pm 70$ 800 .

Charcoal in sand (NMC-762), 8N6E. Late Taltheilei ca AD 400 to

S-1022. Migod site, Level 2

$2240 \pm 80$ 800 .

Charcoal in sand (NMC-763), 2N0E. Early Taltheilei ca AD 200 to

S-1023. Migod site, Level 2 $3720 \pm 80$ 800 .

Charcoal in sand (NMC-764), 16N6E. Early Taltheilei ca AD 200 to

S-1024. Migod site, Level $2 b$

$2080 \pm 120$ 800 .

Charcoal in sand (NMC-765), 10N4E. Early Taltheilei ca AD 200 to

S-982. Migod site, Level 4

$3680 \pm 160$

Charcoal in sand (NMC-766), 8N4E. General Shield Archaic ca 2000 to 5000 BC.

S-1025. Migod site, Level 2c

$2610 \pm 210$ to 400

Charcoal in sand (NMC-767), 20N10E. Earliest Taltheilei ca AD 200

S-1026. Migod site, Level 4c

$5490 \pm 100$

Charcoal in sand (NMC-768), 8N2E. Early Shield Archaic ca 4000 to $6000 \mathrm{BC}$.

S-1158a. Migod site, Level la

$1020 \pm 230$

Charcoal in sand (NMC-831), 10N6E, immediately overlying $1 \mathrm{~b}$ and under Level 1 . Should be older than protohistoric by several centuries ca AD 800 to 1400 .

S-1158b. Migod site, Level la $220 \pm 110$

Charcoal and sand mixture (NMC-831) included uncertain apparent carbonaceous materials.

S-1159. Migod site, Level 1

$$
270 \pm 90
$$

Charcoal in sand (NMC-832), $80 \mathrm{~cm}$ depth, immediately overlying Level 1. Late prehistoric Chipewyan. Should give finite date linking 
prehistoric to historic occupation as recorded by Hearne (1771). Ca 200 to 500 yr BP.

General Comment (BG): of 21 dates, only S-1010 and -1023 are unacceptable. S-1010 too late for Shield Archaic as adjoining Sq 8N4E dated 1730 BC (S-982) and other Shield Archaic levels and sublevels within interval 2820 to 3535 BC. Also from below dominant clay level containing Pre-Dorset artifacts (S-978) and projectile point fragment from $8 \mathrm{~N} 2 \mathrm{E}$ joins fragments from $8 \mathrm{~N} 4 \mathrm{E}$. S-1023 from above clay level too old, based on projectile point base from general Level 2 which is Taltheilei, assigned Middle Taltheilei because of apparent incipient shoulder scar. True age of S-1158 probably between two determinations which would agree with Sub-level 16 and Level 1, above. Estimate of Level 1, ca AD 1300 and la, ca AD 1100. Some dates earlier than expected based on assumption Taltheilei would be later with approach to Hudson Bay. Earliest date for Taltheilei in $\mathrm{E}$ half of barren grounds.

\section{Migod Island site series, Northwest Territories}

Charcoal in sand from site (KkLn-13), on island in Grant Lake, Dubawnt R, Dist Keewatin $\left(63^{\circ} 43^{\prime} 40^{\prime \prime} \mathrm{N}, 100^{\circ} 26^{\prime} 45^{\prime \prime} \mathrm{W}\right)$. Two Taltheilei tradition components based on surface collns and test pits. Level 1 yielded artifacts, Level 2, flakes only. Older surface artifacts may be assoc with Level 2, which should date ca 1500 yr BP. Coll 1974 by C Arnold and B C Gordon; subm 1974 by B C Gordon.

\section{S-1006. Migod Island site, Level 2}

$3280 \pm 80$

Charcoal in sand (NMC-755) from Test Pit A, 25 to $40 \mathrm{~cm}$ depth, $10 \mathrm{~cm}$ below Level 1. Assoc with flakes. Should date earliest evidence of Chipewyan occupation on Migod I., which implies boat travel.

\section{S-1019. Migod Island site, Level 2}

$1990 \pm 80$

Charcoal in sand (NMC-760), $50 \mathrm{~cm}$ depth, ca 1000 to $1500 \mathrm{yr}$ BP. General Comment (BCG): acceptable dates. S-1006 estimate based on simple quartzite flakes, lower level. Pre-Dorset people also used quartzite and probably first occupied site. Middle Taltheilei projectile point on surface fits Middle Taltheilei date.

\section{Cactus Flower site series, Alberta}

Bone and charcoal from site (E60p-16), on flood plain of $\mathrm{S}$ Saskatchewan R, $625 \mathrm{~m}$ asl $\left(50^{\circ} 15^{\prime} \mathrm{N}, 110^{\circ} 38^{\prime} \mathrm{W}\right)$. Stratified campsite, 10 defined occupations separated by periodic river flood alluvial deposits. Occupations designated from latest to earliest, I through X. I and II, Pelican Lake phase, III to IX attributed to McKean complex, X undefined. Coll 1974 by L Bitz, R Freeman, and J Brumley; subm 1975 by J Brumley, Univ Calgary.

\section{S-1011. Cactus Flower site, Occupation I $\quad 2770 \pm 100$}

Bone (NMC-784) from Excavation Unit 6. All bones in unit, $8 \mathrm{~m}$ by $20 \mathrm{~m}$ area. Should date most recent of 2 Pelican Lake phase components ca 2000 to $3000 \mathrm{yr}$. 
Bone (NMC-785) from Excavation Unit 6. All bone from Occupation II in unit. Should date earliest of 2 Pelican Lake phase components ca 2000 to $3000 \mathrm{yr}$.

\section{S-1013. Cactus Flower site, Occupation III $3930 \pm 110$}

Charcoal (NMC-786) from fill of Feature 3, shallow excavated earth pit, Unit $6, \mathrm{Sq} 6 \mathrm{~S} 0 \mathrm{~W}$ and $8 \mathrm{~S} 0 \mathrm{~W}$. Should date most recent McKean phase occupations and provide near terminal date for McKean phase in Plains area, ca 3000 to $3500 \mathrm{yr}$.

\section{S-1209. Cactus Flower site, Occupation III $\quad 3740 \pm 100$}

Charcoal (NMC-852) from fill of Feature 33, shallow earth pit, in XU-6, Sq 16S6W and 18S6W.

\section{S-1210. Cactus Flower site, Occupation VIII $4220 \pm 130$}

Charcoal (NMC-853) from fill of Feature 14, basin hearth in XU-1, Sq 4S10W. Most intensive McKean occupation of site. Should clarify previous dates for occupations VIII and IX (S-782, -783, -821: R, 1975, v 17, p 351-352) ca 4100 yr.

General Comment (JB): S-1013 ca 300 to 400 yr too early for stratigraphic position, other site occupation dates (S-784, -820, -821, -822: R, 1975, v 17, p 352) and dated Pelican Lake phase components elsewhere. S-1011, $-1209,-1210$ acceptable. Evaluation of 12 dates suggests 7 McKean occupations at site date between 3500 and $4300 \mathrm{yr}$ BP.

\section{Cherry Point site series, Manitoba}

Bone from multicomponent site (DkMe-10), near Oak Lake, SW Manitoba $\left(49^{\circ} 42^{\prime} 30^{\prime \prime} \mathrm{N}, 100^{\circ} 43^{\prime} \mathrm{W}\right)$. From three living floors, OxbowMcKean site. Coll 1974 by J Haug; subm 1975 by E L Syms.

$\begin{array}{lll}\text { S-1029. } & \text { Bone (Br-1-Ce), lowest occupation } & 2860 \pm 210 \\ \text { S-1030. } & \text { Bone (Br-1-Ca), lowest occupation } & 2830 \pm 260 \\ \text { S-1031. } & \text { Bone (Br-1-Cb), central occupation } & 1850 \pm 100 \\ \text { S-1032. } & \text { Bone (Br-1-Cd), central occupation } & 2060 \pm 130 \\ \text { S-1033. } & \text { Bone (Br-1-Ce), upper occupation } & 1020 \pm 110 \\ \text { S-1034. } & \text { Bone (Br-1-Cf), upper occupation } & 1040 \pm 190\end{array}$ General Comment (ELS): dates for each living floor cluster closely and stratigraphically consistent but more recent than anticipated (Haug, 1976; Gibson, 1976).

\section{Kenai 29 site series, Alaska}

Charcoal from site, $15.2 \mathrm{~m}$ asl, near Soldatna on Kenai R, Kenai Peninsula $\left(63^{\circ} 31^{\prime} 20^{\prime \prime} \mathrm{N}, 151^{\circ} 07^{\prime} 20^{\prime \prime} \mathrm{W}\right)$. Material tentatively indicates affinity to Kachemak II and Old Kiavak. Coll 1971 by D R Reger; subm 1975 by D W Clark. 
S-1040. Kenai 29 site, Sq F-7

$2560 \pm 300$

Charcoal (NMC-518), N $46 \mathrm{~cm}$ W $20 \mathrm{~cm}, 8 \mathrm{~cm}$ depth. Should date uppermost layer, ca 1000 to $1500 \mathrm{yr}$.

S-1041. Kenai 29 site, Sq E-8

$2250 \pm 120$

Charcoal (NMC-519), N $5 \mathrm{~cm}$ W $61 \mathrm{~cm}, 76 \mathrm{~cm}$ depth. Should date base of lowermost layer, ca 2500 to $3000 \mathrm{yr}$.

General Comment (DWG): apparent discrepancy, S-1041 from basal cultural sediments in direct assoc with house floor, hearth and birchbark basket considered most accurate. Sample contents described elsewhere (Reger, 1977).

\section{Cottonwood Creek site series, Alaska}

Charcoal from site (Sel 30), 51.2m, Cottonwood Creek, Kachemak Bay, Kenai Peninsula $\left(59^{\circ} 44^{\prime} \mathrm{N}, 151^{\circ} 05^{\prime} \mathrm{W}\right)$. Kachemak tradition of Pacific Eskimoid affiliation. Previously investigated by $\mathrm{F}$ Delaguna, reinvestigated by W B Workman (1977). Coll 1974 by J Lobdell, M Clock, and W B Workman; subm 1975 by W B Workman, Alaska Methodist Univ.

S-1042. Cottonwood Creek site, Sec 2-4W, 2-4S $1750 \pm 70$

Charcoal from plank (NMC-797), $325 \mathrm{~cm}$ below surface. From structure at base of midden. Should provide near basal date for occupation which occupies important place in Pacific Eskimo area sequence. Could be from driftwood and older than house, comparable to S-1043. Ca AD $700 \pm 200$.

\section{S-1043. Cottonwood Creek site, $X$ trench $S$ extension} $1750 \pm 130$

Charcoal from plank (NMC-798) from Sec X-3, 170 to $180 \mathrm{~cm}$ below surface. Possibly driftwood.

S-1054. Cottonwood Creek site, Sec 0-2W, 0-2S $1560 \pm 80$

Charcoal (NMC-804) from SE quad, directly below Burial 2, $100 \mathrm{~cm}$ below datum, ca $10 \mathrm{~cm}$ below top of old midden deposit, major stratigraphic unit at site. Old midden separated from upper component by large culturally sterile deposit. In conjunction with S-1042 and -1043, should bracket main occupation and indicate time interval of overlying sterile layer. Ca AD $1100 \pm 200$.

S-1055. Cottonwood Creek sie, Sec 2-4S, 0-2E $1630 \pm 70$

Charcoal (NMC-805) from lower portion Level 2, $20 \mathrm{~cm} \mathrm{~N} 10 \mathrm{~cm} \mathrm{E}$, 10 to $20 \mathrm{~cm}$ below surface. Several triangular slate end blades and rock feature in Level 3 below. Should date upper component with small but distinctive artifacts of late prehistoric culture not previously sampled in Kachemak Bay. Also help bracket sterile level below. Ca AD 1400 \pm 300 .

General Comment (WBW): S-1042 and -1043 provide near basal date, presumed driftwood and may be one or more centuries older than 
occupation. S-1054 tentatively acceptable although older than anticipated, suspect as upper limiting date for main occupation without substantiation. Dates indicate main Kachemak III deposits laid down within a few centuries. S-1055 rejected as dating uppermost Kachemak IV component because significant typologic break between these materials and main deposits. Components separated by sterile silt interbedded with volcanic ash suggest gradual in situ accumulation. Intrusive charcoal introduced by Kachemak IV inhabitants.

\section{Bérubé site series, Quebec}

Charcoal from site (DdGt-5), E shore of Lake Abitibi, ca $3.2 \mathrm{~km}$ from mouth of Duparquet R, Palmarolle Municipality (48 $\left.39^{\prime} \mathrm{N}, 79^{\circ} 19^{\prime} \mathrm{W}\right)$. Cultural affiliation undetermined. Coll 1972 by P Courbin, 1973 by P Leblanc and P Gauthier, and 1974 by J Dubois and R Wilmeth for R Marois; subm 1975 by R Marois, Natl Mus Canada.

\section{S-1048. Bérubé site, Sq W4}

$$
140 \pm 70
$$

Charcoal (NMC-799) Level 2, Zone A, SW Quad Sec B, $13 \mathrm{~cm}$ below surface. Assoc with potsherds in SE quad of same sq, decorated with zone of oblique impressions made by notched implement held perpendicular to surface, above zone of oblique impressions by perpendicularly held spatula. Impressions characteristic of Laurel tradition, principal manifestations of which lie to SW and indicate tradition influence in Abitibi region. Ca AD 400.

\section{S-1049. Bérubé site, Sq S7E3}

Charcoal (NMC-800) from Level 2, Zone A, NE Quad Sec A, 6cm below surface. Assoc with potsherds decorated by two-strand cord impressions on lip and rim. Date will indicate chronologic variation of materials in terms of horizontal and vertical distributions. Ca AD 800.

\section{S-1050. Bérubé site, Sq S4E7}

$540 \pm 60$

Charcoal (NMC-801) from Level 2, Zone B, NW and SE Quads Sec A, 12 to $15 \mathrm{~cm}$ below surface. Assoc with elongated point and potsherds decorated with two-strand cord impressions on lip and rim with exterior punctates and interior nodes. Ca AD 800.

\section{S-1051. Bérubé site, Sq S1E7}

$710 \pm 60$

Charcoal (NMC-802) from Level 2, Zone B, SW and SE Quads Sec A, $14 \mathrm{~cm}$ below surface. Assoc with potsherds decorated with zone of oblique impressions above zone of horizontal impressions of two-strand cord. Ca AD 800.

\section{S-1151. Bérubé site, Pit 03}

Charcoal (NMC-841) from Level 2, Zone A, SW Quad Sec B, $13 \mathrm{~cm}$ below surface. Assoc with potsherds described for S-1048.

S-1152. Bérubé site, Pit S7E3

Charcoal (NMC-842) from Level 2, Zone A, NE Quad Sec A, $6 \mathrm{~cm}$ below surface. Assoc with potsherds described for S-1049. 
General Comment (RM): Level 2, Zone A dates too recent for assoc ceramics, possible intrusion of younger charcoal from Level 1. At least indicates older occupation of Level 2, Zone B than Level 2, Zone A.

Chugachik (Indian) Island site series, Alaska

Birchbark and charcoal from site (Sel 033), in cove on E side Chugachik I. (59 $\left.44^{\prime} 45^{\prime \prime} \mathrm{N}, 151^{\circ} 02^{\prime} 25^{\prime \prime} \mathrm{W}\right)$. Sea level midden site of Kachemak tradition, probably Kachemak II or Sub III. Older than materials from Cottonwood Creek or Yukon I. (Kachemak III). Deposits in situ more than $2 \mathrm{~m}$ thick and very rich in lithics and artifacts (Workman, 1977). Coll 1974 by C Dye and W B Workman; subm 1975 by W B Workman.

S-1062. Chugachik Island site, N 2-3, E 3-4 $2310 \pm 70$

Birchbark (NMC-806) from thick layer of decayed blue mussel shell above archaeologically sterile peaty black soil of site base, $65 \mathrm{~cm}$ below surface. Saturated deposits, possibly below storm tide marks. Fragmented birchbark basketry with evidence of stitching and twine, presumably made by first occupants, ca $700 \mathrm{BC} \pm 300 \mathrm{yr}$.

S-1063. Chugachik Island site, N 2-3, E 1-2 $1705 \pm 70$

Charcoal (NMC-807) within layer of soil and much fragmented mussel shell, $10 \mathrm{~cm}$ below contact with overlying dark soil (some shell), $55 \mathrm{~cm}$ below datum, $80 \mathrm{~cm}$ below surface. Highest charcoal sample taken, assoc with many artifacts and complete mammal bones. Ca AD $300 \pm 300 \mathrm{yr}$.

General Comment (WBW): S-1062 should approximate true date as birch is short-lived, in accord with cultural assessment. If S-1063 driftwood not more than $300 \mathrm{yr}$ old, it would fall in estimate. S-1063 overlaps two basal dates for Cottonwood Creek, which do not agree with typologic evidence and indicates probably driftwood charcoal. Dates bracket site span as ca $700 \mathrm{yr}$.

\section{Fletcher site series, Alberta}

Unburned butchered bone fragments from site (DjOu-1), S Alberta $\left(49^{\circ} 36^{\prime} \mathrm{N}, 111^{\circ} 50^{\prime} \mathrm{W}\right)$. From two closely spaced levels, presumed Cody complex (Forbis, 1968) possibly assoc with large side-notched points. No diagnostic artifacts with bone, only stratigraphic correlation to Forbis excavation. S-1083 identical to portion dated $5960 \pm 170$ yr BP (RL-560: unpub) (Quigg, 1976). Coll and subm 1975 by J M Quigg, Archaeol Surv Alberta.

\section{S-1081. Bone, Test 1, Level 8 \\ S-1082. Bone, Test 1, Level 9 \\ S-1083. Bone, Test 5, Level 11 \\ S-1084. Bone, Test 5, Level 12}

$1680 \pm 150$

$4470 \pm 120$

$4130 \pm 120$

$7660 \pm 110$

General Comment (JMQ): S-1084 just fits time frame for Cody complex in central and $\mathrm{N}$ plains (Wheat, 1972). Dates unreliable because of fluctuating groundwater table and mineral soil. 


\section{S-1135. JjNi-2 site series, Northwest Territories}

Charcoal in sand (NMC-819) from NE Rennie Lake, SE Dist Mackenzie $\left(61^{\circ} 37^{\prime} 30^{\prime \prime} \mathrm{N}, 105^{\circ} 25^{\prime} \mathrm{W}\right)$. From single buried level in blowout exposure, 390 to $450 \mathrm{~m}$ asl. Surrounding artifacts, Late Taltheilei, ca AD 1200 to 1650 . Coll 1975 by M Wright; subm 1975 by B C Gordon.

\section{S-1135. JjNi-2 site}

$2570 \pm 120$

Single buried level in blowout.

\section{S-1157. JjNi-2 site}

$2150 \pm 130$

Single buried level, as above.

General Comment (BCG): estimate based on surface Lake Taltheilei tools dated elsewhere ca AD 1200 to 1650 . Blowout also yielded lesser quantities of Shield Archaic and Pre-Dorset material, 3 diagnostic Early Taltheilei points, 1 diagnostic Late Taltheilei point and non-diagnostic both large and small, crude and fine bifacial knives, several point fragments. Crudity suggests Late Taltheilei side-notched points but may be hafted knives dating much earlier. S-1135 probably dates diagnostic Early Taltheilei ca 500 to 100 BC within error. S-1157 may date knives rather than points.

\section{Côteau-du-Lac series, Quebec}

Human bone from site (BhFn-1), W bank St Lawrence R, ca $7 \mathrm{~km}$ from Valleyfield, Soulanges $\left(45^{\circ} 17^{\prime} 20^{\prime \prime} \mathrm{N}, 74^{\circ} 10^{\prime} 20^{\prime \prime} \mathrm{W}\right)$. From $\mathrm{S}$ of Delisle R, on point formed by $\mathrm{R}$ with St Lawrence. Recovered in cloverleaf bastion, from ground disturbed by construction ca 1778. Two human femurs found out of position in Sq S4, NW quad, $1.76 \mathrm{~m}$ below rampart surface. Two burials discovered in place under $2 \mathrm{~m}$ rampart. 1966 discovery contained a bannerstone; 1975 contained bone knives, 2 elongated net sinkers, and mica sheet. Material exhibits elements common to Laurentian tradition ca 4000 BC. Coll 1975 by F Passchier; subm 1975 by $\mathrm{R}$ Marois.

S-1154. Côteau-du-Lac site

$6660 \pm 150$

Human femur (NMC-844) from Sq S4, NW quad.

\section{S-1263. Côteau-du-Lac site}

$4900 \pm 80$

Human femur (NMC-889) from 1975 grave discovery.

General Comment (RM): no explanation for age difference between disturbed zone femur and grave femur.

\section{Nunguvik Site Series 2, Northwest Territories}

Plant material, bone, and charcoal from site (PgHb-1) S of Low Point, W coast Navy Board Inlet, Baffin I. $\left(73^{\circ} 01^{\prime} 30^{\prime \prime} \mathrm{N}, 80^{\circ} 38^{\prime} 00^{\prime \prime}\right.$ W). N Baffin I., Dorset, and Thule houses site. Coll 1975 and subm 1976 by Fr G Mary-Rousselière. 
S-1202. Nunguvik site, House 76

$2090 \pm 50$

Charcoal (NMC-845) from Sq 43, $15 \mathrm{~cm}$ below surface. Previously dated 1310, 1525, and 1515 BP (S-845, -883, and -849). Ca 1250 to 1300 yr BP.

S-1203. Nunguvik site, House 73

$1940 \pm 100$

Plant material (mostly willow and Cassiope tetragona) (NMC-847) $1 \mathrm{~m}$ asl, Sq 19, 50 to $60 \mathrm{~cm}$ below surface under pavement. Should date earliest Dorset house occupation. Previous dates 1490 вP for alcove NE entrance (S-846) and 1320 BP lower level of entrance passage (S-879). Ca $1550 \mathrm{yr}$.

S-1204. Nunguvik site, House 73

$1470 \pm 90$

Plant material (mostly willow and Cassiope tetragona) (NMC-847) Sq 19 and 22, $30 \mathrm{~cm}$ below surface. Should indicate main Dorset occupation, ca $1500 \mathrm{yr}$.

S-1205. Nunguvik site, House 73

$1090 \pm 90$

Caribou bones (NMC-848) Sq 22, contained in surface to $15 \mathrm{~cm}$ depth. Should date late occupation, perhaps after house abandoned ca 1200 to $1250 \mathrm{yr}$.

S-1206. Nunguvik site, House 73

$1550 \pm 60$

Plant material (mostly Cassiope tetragona) (NMC-849) Sq 17, lower layer 60 to $65 \mathrm{~cm}$ below surface. Should indicate earliest occupation, $\mathrm{Sq}$ 17 house complex to NE of entrance, ca $1550 \mathrm{yr}$.

\section{S-1207. Nunguvik site, House 46}

$1280 \pm 60$

Caribou bones (NMC-850) 12m asl, three squares outside back wall, mostly from $20 \mathrm{~cm}$ depth. Should indicate early Dorset occupation. Previous date $1880 \mathrm{yr}$ BP (S-880) too recent. Ca $2200 \mathrm{yr}$.

General Comment (GM-R): S-1204, -1205, -1206 acceptable. S-1202 too old for recent occupation in House 76. S-1203 seems too old for lower level and S-1207 too recent.

\section{S-1221. FbOq-62 site, Alberta}

$140 \pm 60$

Aspen wood (Populus sp) from set of plains tipi poles, Neutral Hills, $\mathrm{E}$ central Alberta $\left(52^{\circ} 10^{\prime} \mathrm{N}, 110^{\circ} 50^{\prime} \mathrm{W}\right)$. Partially decayed, coll on surface by D Barr (Quigg, 1977). Coll and subm 1976 by J M Quigg. Comment (JMQ): date acceptable.

\section{S-1238. FbOr-57 site, Alberta}

$480 \pm 50$

Charcoal from Neutral Hills, E central Alberta $\left(52^{\circ} 10^{\prime} \mathrm{N}, 110^{\circ} 50^{\prime}\right.$ W). From central hearth in tipi ring 2 of 5 tipi ring site, assoc with small side-notched points (Quigg, 1977). Coll and subm 1976 by J M Quigg. Comment (JMQ): date appropriate for Late Prehistoric period, Old Women's phase. 
FbOv-1 Buffalo Jump and Campsite series, Alberta

Bone from FbOv-1 site, on $\mathrm{N}$ valley wall, Battle R, SW of Alliance $\left(52^{\circ} 20^{\prime} \mathrm{N}, 110^{\circ} 36^{\prime} \mathrm{W}\right)$. From kill deposits; presumed assoc with small plains side-notched points recovered in campsite. Coll 1976 by D Barr and D Buchko; subm 1976 by J M Quigg.

\section{S-1239. Bone, Test 4}

$380 \pm 90$

235 to $260 \mathrm{~cm}$ below surface.

\section{S-1240. Bone, Test 1}

10 to $30 \mathrm{~cm}$ below surface.

General Comment (JMQ): dates acceptable for Late Prehistoric occupation in parkland, central Alberta.

\section{S-1262. EiBg-20 site, Quebec}

$6220 \pm 70$

Charcoal (NMC-887) from ca $2 \mathrm{~km} \mathrm{~N}$ of Blanc Sablon, $30.5 \mathrm{~m}$ asl terrace W of Blanc Sablon R $\left(51^{\circ} 26^{\prime} 44^{\prime \prime}\right.$ N, $\left.59^{\circ} 09^{\prime} \mathrm{W}\right)$. Scattered in Sq S1E3, 30 to $50 \mathrm{~cm}$ below surface, above artifacts and $5 \mathrm{~cm}$ under paleosol assoc with edged biface. Materials include short contracting stem points and scrapers, mostly of rose quartzite. Site assignable to Maritime Archaic. Should date occupation under paleosol ca 6000 BC. Coll 1976 by M Ferdais; subm 1976 by R Marois. Comment (RM): terrace elev and distance to nearest water suggest date is too recent. Assoc not close, hence, date may apply to another phenomenon.

\section{Michipicoten Harbour site series, Ontario}

Charcoal from site (CIIf-2), ca $213 \mathrm{~m}$ from shore of Michipicoten Bay, Lake Superior, Dist Algoma (47 $57^{\prime} 25^{\prime \prime}$ N, $84^{\circ} 51^{\prime} 10^{\prime \prime}$ W) $192 \mathrm{~m}$ asl. Initial Woodland site of Laurel tradition with single living floor. Possible date for introduction of ceramics in Michipicoten area. Coll 1971 by J Reddon and C MacKinnon; subm 1976 by K T Buchanan and M Brizinski, Laurentian Univ.

S-1264. Michipicoten Harbour site, Sq 10N10E $310 \pm 110$

Charcoal (NMC-874) from NW quad, depth $45.2 \mathrm{~cm}$. From hearth on living floor, ca 2000 to $2500 \mathrm{yr}$.

\section{S-1265. Michipicoten Harbour site, Sq 10N20E $3120 \pm 430$}

Charcoal (NMC-875) from $1.7 \mathrm{~m} \mathrm{~N}$ by $2.6 \mathrm{~m} \mathrm{~W}$, depth $25.4 \mathrm{~cm}$. From hearth on living floor, assoc with Laurel sherds, ca 2000 to $2500 \mathrm{yr}$.

General Comment (KTB and MB): S-1264 unacceptable in view of artifact evidence. S-1265 probably represents earliest possible date for Laurel culture in Lake Superior area. Provides some idea of subsidence rate of prehistoric Lake Nipissing in Superior Basin. Site at $192 \mathrm{~m}$ asl, $8.5 \mathrm{~m}$ above Lake Superior was probably lake level beach used as summer animal procurement-processing site. Minimum time depth correlates with hypothesized date of $700 \mathrm{BC}$ for introduction of Laurel culture by $\mathrm{J} \mathrm{V}$ Wright. 


\section{S-1266. Wawa site, Ontario}

Charcoal (NMC-876) from site (ClIf-8), ca $483 \mathrm{~m}$ upstream from mouth of Michipicoten R, N bank, Dist Algoma $\left(47^{\circ} 56^{\prime} 06^{\prime \prime} \mathrm{N}, 84^{\circ} 50^{\prime}\right.$ $33^{\prime \prime}$ W). From balk at junction Sqs A3, A4, B3, B4; depth $17.8 \mathrm{~cm}$. Stratified site, $191 \mathrm{~m}$ asl, from historic Level 1 to Initial Woodland basal cultural layer. Assoc with Laurel sherd cluster. Coll 1971 by C MacKinnon; subm 1976 by K T Buchanan and M Brizinski. Comment (KTB and MB): site on elev ledge ca $7.6 \mathrm{~m}$ above present level of Michipicoten $\mathrm{R}$, probably former shore of large bay. Laurel ceramics are later than ClIf-2 site.

\section{Radiant Lake 3 site series, Ontario}

Charcoal from site (CaGn-1), in sandy soil atop knoll, $14 \mathrm{~m}$ above Radiant Lake, Deacon Twp $\left(46^{\circ} 00^{\prime} 07^{\prime \prime} \mathrm{N}, 78^{\circ} 17^{\prime} 58^{\prime \prime} \mathrm{W}\right)$. Multicomponent site. Coll 1966-1968, 1971 by P Butler, D Croft, and B M Mitchell; subm 1976 by B M Mitchell, Deep River, Ontario.

S-1267. Radiant Lake 3 site, Sq $I 19$

$310 \pm 80$

Charcoal (NMC-864) in hearth feature containing sherds, 15 to $18 \mathrm{~cm}$ below surface. Should date makers of cord-malleated collarless ceramics, ca $1200 \mathrm{yr}$.

\section{S-1289. Radiant Lake 3 site, Sq 021}

$1300 \pm 70$

Charcoal (NMC-867) from 25.5 to $30.5 \mathrm{~cm}$ below surface. Middle Woodland hearth producing rim sherds decorated with horizontal lines of pseudo-scallop shell, ca $2300 \mathrm{yr}$.

S-1290. Radiant Lake 3 site, Sq $126 \quad 3010 \pm 110$

Charcoal (NMC-868) from 13 to $35.5 \mathrm{~cm}$ below surface. Hearth producing cord-malleated sherds, ca $1200 \mathrm{yr}$.

\section{S-1292. Radiant Lake 3 site, Sq J27}

$8690 \pm 690$

Charcoal (NMC-870) from 28 to $35.5 \mathrm{~cm}$ below surface, assoc with slate chips and bone. Should date Archaic occupation between 4815 and $4150 \mathrm{yr}$.

\section{S-1298. Radiant Lake 3 site, Sq H29/I29}

$350 \pm 60$

Charcoal (NMC-285) from border between Sq H29 and I29, 5 to $10 \mathrm{~cm}$ below surface, among plain and incised Iroquois body sherds. Side-notched and Black-Necked rim sherds occurred nearby, same level. Approx historic contact.

\section{S-1299. Radiant Lake 3 site, Sq H26}

Charcoal (NMC-873) from 30.5 to $33 \mathrm{~cm}$ below surface, hearth feature. Should date makers of cord or fabric-malleated pottery, E central Ontario, ca $1200 \mathrm{yr}$.

General Comment (BMM): S-1298 and -1299 confirm possibility that malleated pottery component divisible into two sub-zones. Fabric-malleated vessels were in use AD 1645 (S-1267) and AD 1620 (GSC-1529: 
unpub), cord-malleated vessel in AD 710 (GSC-1351: unpub). Date S-1299 acceptable but S-1290 too early. S-1289 late for Middle Woodland deposits but acceptable. S-1292 very early but possible, previous dates average ca $4500 \mathrm{yr}$ (GSC-1281: unpub; S-1162 and -1163: R, 1979, v 21, p 82). S-1298 good date for assoc Iroquoian ceramics, Ottawa Valley.

\section{CbGj-1 site series, Ontario}

Charcoal from sandy beach $1.2 \mathrm{~m}$ above Ottawa $\mathrm{R}$, near Deep River $\left(46^{\circ} 10^{\prime} 54^{\prime \prime} \mathrm{N}, 77^{\circ} 36^{\prime} 30^{\prime \prime} \mathrm{W}\right), 113 \mathrm{~m}$ asl. Middle Woodland site with intrusive Iroquoian sherds. Coll 1969, 1970, and subm 1976, 1977 by B M Mitchell.

\section{S-1268. CbGj-1 site, Sq 13}

Charcoal (NMC-865) from depth $19 \mathrm{~cm}$, ca $2200 \mathrm{yr}$.

S-1269. CbGj-1 site, Sq 7F

$870 \pm 130$

Charcoal (NMC-866) from small hearth containing corn-ear rim sherd, ca $400 \mathrm{yr}$.

\section{S-1301. CbGj-1 site, Sq 106B}

$$
\mathbf{3 8 3 0} \pm \mathbf{1 3 0}
$$

Charcoal (NMC-890) from depth 18 to $25 \mathrm{~cm}$, small hearth feature containing many lithic chips and two Iroquoian sherds, ca 400 to $800 \mathrm{yr}$. General Comment (BMM): S-1268 later than expected but within range of Middle Woodland. S-1269 appears too early, but rims from Iroquoian component at BlGk-15 site, on Petawawa R, 30km W, dated AD $1270 \pm$ 80 (GSC-2238: unpub) Mitchell et al, 1970). S-1301 unacceptable for assoc sherds.

\section{Protection Island site series, British Columbia}

Charcoal from site (DhRx-5), NW shore Protection I., E off Nanaimo, Vancouver I. $\left(49^{\circ} 10^{\prime} 50^{\prime \prime} \mathrm{N}, 123^{\circ} 55^{\prime} 22^{\prime \prime} \mathrm{W}\right)$. Small shallow shelf midden overlying portions of otherwise undisturbed petroglyph pecked into sandstone slab, seaward midden edge. Midden ca $4 \mathrm{~m}$ above high tide overlooking shallow tidal channel between Protection I. and Newcastle I. Artifacts suggest developed Coast Salish culture common to region. Should be min date for petroglyph and occupation, ca 300 to 1000 yr. Coll 1975 by D Lundy, A McMurdo, D Hutchcroft, B Kennedy, and M Abbott; subm 1976 by D Lundy, Prov Mus, British Columbia.

\section{S-1270. Protection Island site, Level $4 \quad 280 \pm 50$} depth.

Charcoal (NMC-871) scattered throughout Level 4,40 to $43 \mathrm{~cm}$

S-1271. Protection Island site, Level $1 \quad 350 \pm 40$

Charcoal (NMC-872) found in scattered chunks in Level 1, 59 to $80 \mathrm{~cm}$ depth, Unit 2.

General Comment (1)L): oral commun with residents and soil analyses support no recent site disturbance. Recovered artifacts indicate historic and prehistoric cultural components. Minimum date for rock carving. 


\section{Stott site series, Manitoba}

Bone from site (DlMa-1), large Late Woodland, Blackduck site along Assiniboine R, transition zone between NE Plains and Aspen Parkland, near Brandon ( $\left.49^{\circ} 52^{\prime} 30^{\prime \prime} \mathrm{N}, 100^{\circ} 05^{\prime} \mathrm{W}\right)$. Multicomponent, from base of thick bone bed (Syms, 1976b; 1977; Tisdale, 1978). Coll and subm 1976 by E L Syms.

$$
\begin{array}{lll}
\text { S-1272. } & \text { Bone (BU-76-1), Level } 6 & 1110 \pm 60 \\
\text { S-1273. } & \text { Bone (BU-76-2), Level } 6 & 1040 \pm 50
\end{array}
$$

General Comment (ELS): dates acceptable.

\section{Bruce Boyd series, Ontario}

Charcoal and deer bone from site (AdHc-4) sand knoll, Lots 8 and 9, Concession B, S Walsingham Twp, Norfolk Co $\left(42^{\circ} 36^{\prime} \mathrm{N}, 80^{\circ} 28^{\prime} \mathrm{W}\right)$. Early Woodland burial site, $171 \mathrm{~m}$ asl. Closest affiliations appear to be Meadowood, New York. Coll 1976 by M Spence, R Williamson, and J Dawkins; subm 1977 by M Spence, Univ Western Ontario.

\section{S-1287. Bruce Boyd site, Feature $3 \quad 860 \pm 70$}

Charcoal (NMC-903) from Sq 495-500. Probably Early Woodland ca 700 to 400 BC.

\section{S-1288. Bruce Boyd site, Feature 15}

Deer bone (NMC-904) from Sq 490-500, burial pit, directly above human remains, 10 to $15 \mathrm{~cm}$ below top soil. Assoc directly as offering with probable Early Woodland burial ca 700 to $400 \mathrm{BC}$.

General Comment (MS): S-1287 dates minor Late Woodland site use. Ceramic analyses from feature revealed 1 Glen Meyer body sherd and others part of 3 Early Woodland vessels. Date acceptable for Glen Meyer ceramics. S-1288 Early Woodland occupation agrees with three dates from 600 to $470 \mathrm{BC}$ for Early Woodland Dawson Creek site on Rice Lake and dates series for similar New York, Ohio, and Michigan sites. Date suggests Bruce Boyd site contemporary with earlier part of Saugeen focus of Bruce Peninsula, but it is possible that early Saugeen dates from Donaldson site really pertain to distinct Early Woodland (Vinette 1) occupation that became mixed with later dentate-corded stick assemblage.

\section{S-1291. BIGk-15 site, Ontario}

$2580 \pm 170$

Charcoal (NMC-869) from Petawawa R, Algonquin Park, Stratton Twp ( $\left.45^{\circ} 49^{\prime} 10^{\prime \prime} \mathrm{N}, 77^{\circ} 41^{\prime} 45^{\prime \prime} \mathrm{W}\right)$. From ca $155 \mathrm{~m}$ asl, test hole 18 to $25.4 \mathrm{~cm}$ below surface, near shale blade and pseudo-scallop-shell-decorated rim sherds. Should determine if local Middle Woodland culture dates beyond 490 BC (Gak-1891: R, 1973, v 15, p 57). Ca 2400 yr. Coll 1968 and subm 1977 by B M Mitchell. Comment (BMM): date acceptable; probably represents earlier portion of Middle Woodland period. 


\section{Nyman site series, Ontario}

Charcoal from site (CIIf-11), N shore Lake Superior, $805 \mathrm{~m}$ upstream from mouth of Michipicotin R, Michipicotin Bay $\left(47^{\circ} 57^{\prime} 00^{\prime \prime} \mathrm{N}, 84^{\circ} 54^{\prime}\right.$ $30^{\prime \prime} \mathrm{W}$ ). Small habitation, $6.1 \mathrm{~m}$ above $\mathrm{R}$ on $\mathrm{N}$ bank, Terminal Woodland period, Algonkian culture. Coll 1971 and subm 1976 by K C A Dawson, Lakehead Univ.

\section{S-1293. Nyman site, Level IIB}

$80 \pm 70$

Charcoal (NMC-893) from Sq 30W/0N, Stratum III, Hearth Feature $7,12.7$ to $15.2 \mathrm{~cm}$ depth. Assoc with Blackduck and Michigan derived ceramics, lithics, but no trade goods. Ca AD 1400 to 1750.

S-1294. Nyman site, Level II

$530 \pm 90$

Charcoal (NMC-894) from Sq 10W/0N, Stratum II, Hearth Feature $15,17.8 \mathrm{~cm}$ depth. Assoc with historic and prehistoric artifacts, ca AD 1700 to 1750 .

S-1295. Nyman site, Level IIB

$1130 \pm 140$

Charcoal (NMC-895) from Sq $30 \mathrm{~W} / 0 \mathrm{~N}$, Stratum III, Hearth Feature 7, 12.7 to $15.2 \mathrm{~cm}$ depth. Same assoc as S-1293.

S-1296. Nyman site, Level II

Modern

Charcoal (NMC-896) from Sq $10 \mathrm{~W} / 0 \mathrm{~N}$, Stratum II, 5.1 to $12.1 \mathrm{~cm}$ depth. Ca AD 1750.

General Comment (KCAD): discrepancies consistent with arbitrary excavation of naturally disturbed thin cultural mantle of site. S-1293 and -1296 too recent. S-1295 appears too early. S-1294 acceptable for earlier occupation, complements previous date AD $1575 \pm 45$ (S-1294: unpub).

\section{S-1297. Cressman site, Ontario}

$170 \pm 90$

Wood and charcoal (NMC-897) from site (DfJn-1), Lac des Milles Lacs, on sand point ca $6.4 \mathrm{~km}$ SW of Savanne $\mathrm{R}$ mouth, Lac des Milles Lacs Indian Reserve 22A-1, Ontario $\left(48^{\circ} 54^{\prime} \mathrm{N}, 90^{\circ} 18^{\prime} \mathrm{W}\right)$. From hearth, Test Pit 2, $25.4 \mathrm{~cm}$ below surface. Woodland period with Laurel, Blackduck, and historic occupations. Blackduck component ca AD 1000 to 1600. Coll 1976 by M P McLeod; subm 1976 by K C A Dawson. Comment (KCAD): date acceptable for terminal Blackduck historic occupation. Depth of recovery suggested early component, but years of water erosion at site may account for overburden.

\section{Montgomery Lake site series, Ontario}

Charcoal from site (BlGj-2), on sandy slope $3 \mathrm{~m}$ above Montgomery Lake, Wylie Twp $\left(45^{\circ} 56^{\prime} 13^{\prime \prime} \mathrm{N}, 77^{\circ} 33^{\prime} 49^{\prime \prime}\right.$ W). Middle Woodland with Vinette 2 ceramics. Red ocher-stained cremation burial pattern present. Coll 1966, 1967, and subm 1977 by B M Mitchell.

S-1300. Montgomery Lake site, Sq $51 \quad 3360 \pm 80$ yr.

Charcoal (NMC-888), 25 to $38 \mathrm{~cm}$ depth, in hearth feature. Ca 2400 
S-1302. Montgomery Lake site, Sq 26

Charcoal (NMC-891), 18 to $23 \mathrm{~cm}$ depth, in hearth containing sherds, projectile point, beaver jaw bones. Should date latest ceramic use by Iroquoian groups of interrupted-bar motif on collared pottery, ca $400 \mathrm{yr}$. General Comment (BMM): S-1300 later than local Archaic cultures and earliest Middle Woodland but with acceptable limit. S-1302 confirms later part of range of Iroquoian pottery in Ottawa $\mathrm{R}$ drainage.

S-1303. Stott Mound, Manitoba

$1360 \pm 60$

Human bone (NMC-910) from (DlMa-1), on N bank Assiniboine $\mathrm{R}$, near Brandon, Manitoba $\left(49^{\circ} 52^{\prime} \mathrm{N}, 100^{\circ} 05^{\prime} \mathrm{W}\right)$. From Burial XV-A: 97 , Mound probably assoc with Blackduck complex site on basis of proximity to Stott Village site. No Blackduck mound in Manitoba ever before dated. Ca AD 700 to 1400 if Blackduck. Coll 1952 by R S MacNeish; subm 1977 by Roscoe Wilmeth at request of E L Syms. Comment (ELS): date ca $300 \mathrm{yr}$ earlier than anticipated, earlier than any Blackduck dates in Manitoba and lowest level of Stott site bone bed averaging AD $884 \pm 36$. Mound lacked diagnostic artifacts but contained Late Woodland sherdlets (Syms, 1976).

\section{S-1319. Moosehide site, Yukon}

$220 \pm 60$

Bone (NMC-911) from site (LaVk-2), bank Yukon R, $4.8 \mathrm{~km}$ below Dawson City, abandoned village of Moosehide, Yukon $\left(64^{\circ} 06^{\prime} \mathrm{N}, 139^{\circ}\right.$ $\left.26^{\prime} \mathrm{W}\right)$. Multicomponent site on $18.3 \mathrm{~m}$ terrace overlooking mouth of Moosehide Creek. From Level 1, Sq 15, SE sec, assoc with concentration of firecracked rock, chert end scraper, and flakes. Late Prehistoric occupation characterized by crude flake industry, chert end scrapers, blunt-bone hunting arrow point, and probable Klo-kut point. Athapaskan, ca 200 to 1400 yr. Coll and subm 1976 by J R Hunston, Univ Calgary. Comment (JRH): S-1319 acceptable; fits typologic affinities of Late Prehistoric material with late period at Klo-kut, Late Prehistoric Kutchin site, N Yukon (Morlan, 1973).

\section{Cape Garry site series, Northwest Territories}

Wood from site (PeJq-5), max E projection of Cape Garry, Somerset I., Dist Franklin $\left(72^{\circ} 27^{\prime}\right.$ N, $\left.93^{\circ} 28^{\prime} \mathrm{W}\right)$. Thule site of 26 winter houses. Occasional artifacts suggestive of nearby Dorset occupation. No European artifacts. Coll 1967 by A Clarke and A P McCartney; subm 1977 by A P McCartney, Univ Arkansas.

\section{S-1320. Cape Garry site, House 7}

$1070 \pm 70$

Wood (NMC-912) from Sec E-1, lower sod to gravel in permafrost zone, 15 to $30 \mathrm{~cm}$ depth. Should date house occupation, ca AD 1200 to 1400.

S-1321. Cape Garry site, House 6 $\mathbf{5 3 0} \pm \mathbf{8 0}$

Wood (NMC-913) from Sec B-2, floor zone, in permafrost, $50 \mathrm{~cm}$ depth. Should date earliest occupation and probably construction and apply to adjacent houses, ca AD 1200 to 1400. 
S-1322. Cape Garry site, House 18

$910 \pm 60$

Wood (NMC-914) from Sec C-2, floor muck, in front of bench ledge below ca $20 \mathrm{~cm}$ of moss muck, in permafrost zone. Should date earliest occupation and probably construction, ca AD 1200 to 1400.

General Comment (APM): all three houses in same cluster located on same beach ridge. Similarity of artifacts and locality suggests contemporary occupation during classic Thule period. S-1320 appears early, S-1321 too late, S-1322 more closely fits expected early Thule period. Wood probably trade driftwood from mainland, age correction for gap in use important in Canadian Archipelago but difficult to estimate.

\section{Creswell Bay site series, Northwest Territories}

Wood from site (PeJr-1), N shore Creswell Bay, ca $14.5 \mathrm{~km} \mathrm{~W}$ of Creswell R mouth, Somerset I., Dist Franklin $\left(72^{\circ} 48^{\prime} \mathrm{N}, 93^{\circ} 36^{\prime} \mathrm{W}\right)$. Thule site of 16 winter houses. Dorset artifacts but no Dorset structures, no European material. Ca AD 1200 to 1400 . Coll 1976 by D Weetaluktuk, J Sproull, and A Sawicki; subm 1977 by A P McCartney.

\section{S-1323. Creswell Bay site, House 1}

$1010 \pm 100$

Wood (NMC-915) from Sec C-3, floor zone inside house, $50 \mathrm{~cm}$ depth in permafrost.

\section{S-1324. Creswell Bay site, House 15}

$$
830 \pm 70
$$
frost.

Wood (NMC-916) from Sec C-13, floor zone, $40 \mathrm{~cm}$ depth in perma-

\section{S-1325. Creswell Bay site, House 5}

$$
1130 \pm 90
$$

Wood (NMC-917) from Sec B-3, floor zone inside house, $70 \mathrm{~cm}$ depth in permafrost.

General Comment (APM): Houses 1 and 5 close together on same beach ridge suggesting contemporary occupation. Although dates are similar they appear too early in view of earliest Canadian Thule estimates at AD 950 to 1050. House 15, isolated at one edge of house cluster, dates closer to expected age. Artifacts suggest cultural continuity and contemporaneity of houses. Possible driftwood older than construction as Cape Garry site suggests (S-1320, -1321, and -1322).

\section{S-1326. MbDq-1 site, Northwest Territories}

$90 \pm 140$

Wood (NMC-918) from N shore Cumberland Sound, $1.6 \mathrm{~km} \mathrm{~W}$ of historic settlement of Avatuktoo, Baffin I., Dist Franklin $\left(66^{\circ} 15^{\prime} \mathrm{N}, 66^{\circ}\right.$ $19^{\prime}$ W). From House 3, Sec S12W2, Level 18, W living area, 99 to $104 \mathrm{~cm}$ depth in permafrost. Thule site of 9 winter houses, European artifacts present. Should date original occupation, probably house construction but may relate to historic habitation. Ca AD 1200 to 1400 . Coll 1976 by H Stewart; subm 1976 by A P McCartney. Comment (APM): given lack of boulder and slab rock construction (flagstone floor, doorway, and distinct walls, and benches or platforms) typical of Thule houses in E Canadian Arctic, it is possible house might be qarmat structure of 
historic period. Whale bone fragments and small number of artifacts present, none distinctively prehistoric period.

S-1327. Qiqitalakjuak site, Northwest Territories $\quad 620 \pm 80$

Mixed vegetation including wood fragments (NMC-919) from site (MhBw-3), S shore Kikitalakdjuak I., E Baffin I., Dist Franklin $\left(63^{\circ} 30^{\prime}\right.$ $\left.\mathrm{N}, 67^{\circ} 16^{\prime} \mathrm{W}\right)$. From House 2, Sec B-2, Quad 2, between slabs and support rock of outside bench. Thule site of 4 winter houses, 2 excavated. House 1 appears to be originally Thule built and re-occupied in late 18th and early 19th centuries; historic artifacts found in upper levels of house. Ca AD 1600 to 1800. Coll 1976 by G Sabo; subm 1977 by A P McCartney. Comment (GS): date acceptable for general area occupation by ca AD 1200, Thule Eskimo living in semi-subterranean sod-stone houses.

\section{Gompf site series, Manitoba}

Bison bone from site (DkMd-3), on tributary ravine of Assiniboine $\mathrm{R}$ valley, W Manitoba $\left(49^{\circ} 48^{\prime} 30^{\prime \prime} \mathrm{N}, 100^{\circ} 33^{\prime} \mathrm{W}\right)$. Blackduck killcamp site, Excavation B, Level 3, bottom of bone bed, 20 to $30 \mathrm{~cm}$ below surface. Coll and subm 1977 by E L Syms.
S-1366. Bone (Br-77-2)
$1020 \pm 60$
S-1367. Bone (Br-77-3)
$1140 \pm 70$
S-1368. Bone (Br-77-4)
$990 \pm 70$

General Comment (ELS): multiple samples believed to represent single event, shows range of variation.

\section{S-1372. EqPt-6 site, Alberta $\quad \mathbf{3 7 0} \pm \mathbf{8 0}$}

Bone from campsite, on $\mathrm{N}$ side of Bow $\mathrm{R}$ valley just inside $\mathrm{mt}$ front, W Alberta $\left(51^{\circ} 04^{\prime} \mathrm{N}, 115^{\circ} 11^{\prime} \mathrm{W}\right)$. From cultural level $31 \mathrm{~cm}$ below surface, assoc with corner-notched point, biface, end scraper, and lithics (Quigg, 1978). Coll 1977 by D Barr; subm 1977 by J M Quigg. Comment (JMQ): date is considerably outside known range of Pelican Lake Phase for NW Plains and termination date AD 500 to 600 for mts (Reeves, 1970). Few sites in area or cultural phase; date is tentative.

\section{S-1373. Dry Island Buffalo Jump site $\quad \mathbf{5 3 0} \pm \mathbf{8 0}$}

Bone from (ElPf-1), N of Drumheller, Alberta $\left(51^{\circ} 55^{\prime} \mathrm{N}, 112^{\circ} 59^{\prime}\right.$ W). Site not excavated, bone recovered from slump block. Coll 1977 by D Barr; subm 1977 by J M Quigg. Comment (JMQ): date is reasonable for late occupation.

\section{Nakwantlun site series, British Columbia}

Charcoal from site (FdSi-11), E bank of Dean R at Natsedeelya Crossing, just below outlet of lower Anahim Lake $\left(51^{\circ} 31^{\prime} 05^{\prime \prime} \mathrm{N}, 125^{\circ}\right.$ $22^{\prime} 15^{\prime \prime} \mathrm{W}$ ). Multicomponent site, with unknown number of components, ending with late prehistoric or protohistoric Chilcotin. Coll 1977, 1978 by Cohen, F Wilmeth, R Wilmeth, P Stahl, A Barton, J Coates, and D Black; subm 1977, 1978 by Roscoe Wilmeth. 
S-1415. Nakwantlun site, House 2, Level 4

$2410 \pm 100$

Charcoal (NMC-930) from test trench, 63 to $80 \mathrm{~cm}$ below surface.

S-1416. Nakwantlun site, House 5, floor

$1870 \pm 60$

Charcoal (NMC-931) from test trench, floor level.

S-1417. Nakwantlun site, House 6, floor

$2410 \pm 240$

Charcoal (NMC-932) from test trench, floor level.

S-1446. Nakwantlun site, House 8, Level 2

$840 \pm 60$

Charcoal (NMC-961) from test trench, brown soil zone.

S-1589. Nakwantlun site, XU-1, Sq 0-2S, 0-2W

Charcoal (NMC-992) in lower red-brown soil zone.

S-1590. Nakwantlun site, XU-1, Sq 0-25, 4-6E

Charcoal (NMC-993) $53 \mathrm{~cm}$ below surface, red-brown soil zone.

S-1591. Nakwantlun site, XU-1, Sq 2-4S, 6-8E $430 \pm 50$ soil zone.

Charcoal (NMC-994) $10 \mathrm{~cm}$ below surface in humus above red-brown

S-1592. Nakwantlun site, XU-1, Sq 2-4S, 6-8E $180 \pm 40$ soil zone.

Charcoal (NMC-995) $6 \mathrm{~cm}$ below surface in humus above red-brown

S-1593. Nakwantlun site, House 2, Layer 9

$3500 \pm 70$ zone.

Charcoal (NMC-996) 45 to $55 \mathrm{~cm}$ below surface, hearth in gray silt

S-1594. Nakwantlun site, House 2, Layer 9

$2480 \pm 50$ zone.

Charcoal (NMC-997) 55 to $65 \mathrm{~cm}$ below surface, hearth in gray silt

S-1608. Nakwantlun site, House 2, Layer 10

$2370 \pm 70$

Charcoal (NMC-998) 65 to $75 \mathrm{~cm}$ below surface, hearth in light brown silt.

S-1609. Nakwantlun site, House 2, Layer $10 \quad 2530 \pm 50$ silt.

Charcoal (NMC-999) 76 to $81 \mathrm{~cm}$ below surface, hearth in dark gray

S-1610. Nakwantlun site, House 6

$1010 \pm 60$

Charcoal (NMC-1000) from floor in NW quad, $101 \mathrm{~cm}$ below surface.

S-1611. Nakwantlun site, House 6

$500 \pm 45$

Charcoal (NMC-1001) from fill in NW quad, in fire-reddened soil, buried root.

S-1612. Nakwantlun site, House 6

$880 \pm 60$ hearth.

Charcoal (NMC-1002) from red-soil zone, middle of three levels in 
General Comment (RW): dates S-1415, -1417, -1589, -1594, -1608, and -1609 form fairly compact group ranging from 575 to 420 BC. Four samples from House 2, from 2 stratified hearths, with one exception are in proper order. Tight date clustering suggests S-1593 at 1550 BC from upper of 2 hearths in House 2 is too early. These are earliest dates so far obtained at Anahim Lake. S-1416 falls within range of Component Cluster I at Potlach site (FeSi-2), characterized by presence of microblades (Wilmeth, 1978). No microblades yet recovered at Nakwantlun site but parallel house form at 2 sites. S-1446, -1612, and -1610 immediately precede previous dates for Component Cluster III at Goose Point site (FeSi-1), S-1446 comparable to Goose Point (S-1039: R, 1979, v 21, p 82). S-1590, -1591, -1592, and -1611 span period from Late Prehistoric to Protohistoric in Anahim area assoc with small side-notched points, alleged occupation by Chilcotin Indians.

\section{Afo-109 site series, Alaska}

Charcoal from mouth of Afognak R, Afognak I., Kodiak group (58 $05^{\prime} \mathrm{N}, 152^{\circ} 48^{\prime} \mathrm{W}$ ). Campsite ca $5.8 \mathrm{~m}$ asl, $2.44 \mathrm{~m}$ above high tide, early maritime hunters belonging to Ocean Bay II phase. Located within ethnographic Pacific Eskimo territory but not necessarily Eskimo affiliation, lacks cross-ties with N Alaskan sites. Coll 1971 and subm 1977 by D A Clark.

\section{S-1418. 49 Afo-109 site, H sec}

$4480 \pm 160$

Charcoal (NMC-934) from charcoal layers in feature pit, depth 83.8 to $99 \mathrm{~cm}$ below base of 1912 volcanic ash. Ca 3800 to $4800 \mathrm{yr}$.

S-1419. 49 Afo-109 site, Sec S60W106

$4480 \pm 130$

Charcoal (NMC-935) from trimmed erosion face; depth $50.8 \mathrm{~cm}$ below base of 1912 volcanic ash. Ca 3800 to $4800 \mathrm{yr}$.

General Comment (DWC): previous site dates and adjacent Ocean Bay I/I-II site Afo-106 indicated probable overlapping or sequential occupations (Gak-3802, -3803 and -3804: unpub). Previous dates are older (Clark, 1979).

\section{Porden Point Brook series, Northwest Territories}

Twigs, leaves, sphagnum, and bone from Porden Point Brook village (RbJr-1), $1 \mathrm{~km} \mathrm{NW}$ of Porden Point tip, Grinnell Peninsula, Devon I., $\left(76^{\circ} 15^{\prime} \mathrm{N}, 92^{\circ} 40^{\prime} \mathrm{W}\right)$. Thule winter village, 9 houses, $120 \mathrm{~m}$ inland from coast, $4 \mathrm{~m}$ asl. Artifacts suggest early period of Thule occupation in High Arctic. Coll and subm 1977 by R McGhee, Natl Mus Canada.

\section{S-1420. Porden Point Brook site, House 7}

Twigs (NMC-936) from rear of sleeping platform area, beneath flagstones of platform. Sample mixed with moss and leaves, apparent residue from platform mattress. Ca 500 to $1000 \mathrm{yr}$. 
Leaves (Dryus sp) (NMC-937) from rear of sleeping platform area, beneath flagstones of platform. Sample mixed with moss and twigs, similar to S-1420.

\section{S-1422. Porden Point Brook site, House 7}

$1000 \pm 110$

Sphagnum (NMC-938) from rear of sleeping platform area, beneath flagstones of platform. Sample mixture similar as S-1420 and -1421.

\section{S-1423. Porden Point Brook site, House 7}

$1340 \pm 70$

Rib bone sec (Balaena mysticetus) (NMC-939), between flagstones of floor area. Ca 500 to $1000 \mathrm{yr}$.

\section{S-1424. Porden Point Brook site, House 7}

$1310 \pm 70$

Rib bones (Phoca hispida) (NMC-940), beneath flagstones of sleeping plattorm area. Ca 500 to $1000 \mathrm{yr}$.

General Comment (RM): sample series selected for testing relationship between dates on different arctic materials. Four samples from beneath sleeping platform above floor flagstones; whale bone, structural support of house wall, seal bones, apparent refuse, plant materials (mattress residue) picked from single mixed sample found in situ, beneath rear of platform. Excellent preservation of samples; appear continuously frozen since house was abandoned. House 7 typical Thule winter house, appears occupied only for a few years; no evidence of earlier occupation found at site. S-1420 local willow twigs, acceptable for artifact style. Other dates unacceptably early. Possibly, sphagnum was dug from old deposit but there are no signs of humification; appears as if recently picked; no explanation for wide range of plant material dates. Whale bone is possibly from old drift-whale and used much later in house construction. Seal bones undoubtedly relate to house occupation but similar date to whale bone; sea mammal dates expected to be unacceptably early (McGhee and Tuck, 1976) but not as early as S-1423 and -1424. Findings suggest that arctic material dates other than local wood should be treated with some skepticism.

\section{Garden Island site series, British Columbia}

Human bone from site (GbTo-23), Venn Passage, Prince Rupert $\left(54^{\circ} 19^{\prime} 05^{\prime \prime} \mathrm{N}, 130^{\circ} 23^{\prime} 15^{\prime \prime} \mathrm{W}\right)$. Shell midden covering small island in coast Tsimshian area. Coll 1967 by G F MacDonald; subm 1977 by J S Cybulski, Natl Mus Canada.

\section{S-1428. Garden Island site, Burial 165}

$$
1750 \pm 70
$$

Human ribs (NMC-944) from Sq 4AAl, $51.8 \mathrm{~cm}$ below surface, $1.9 \mathrm{~m}$ below datum. Headless skeleton, "discarded" burial position. Crippled condition in life suggested by pelvic and vertebral anomalies. Ca AD 1000 . 
Human ribs (NMC-945) from Area 5, Level 1. Burial position suggests other than prepared burial. Labret wear on lower teeth. Temporomandibular joint arthritis. Ca AD 1000 to 1500.

S-1595. Garden Island site, Burial XVII-B-158 $2800 \pm \mathbf{5 0}$

Human ribs (NMC-1003) from Test Area 5, below humus line. Ca 2000 to $2500 \mathrm{yr}$.

S-1596. Garden Island site, Burial XVII-B-197 $6230 \pm 80$

Right human innominate and head of femur (NMC-1004) from Sq $2 \mathrm{~B}$, ca $2.6 \mathrm{~m}$ below datum. Part of multiple burial; should date lowest cultural level in square.

General Comment (JSC): part of human bone series from five shell midden sites in Prince Rupert Harbour region, British Columbia, for clarification of burial sequence in relation to ${ }^{14} \mathrm{C}$ dated (charcoal and shell) stratigraphy and bracket of possible temporal groups to known or estimated time span of sites. S-1428, -1429, and -1595 agree with chronologic distribution of bone dates from other sites. S-1428 and -1595 agree closely with stratigraphic position estimate. S-1429 suggests need for strata review in Area 5 as field record is not directly connected to other site areas. S-1596 appears wrong, $3000 \mathrm{yr}$ older than any other bone-dated burial from sites. Left humerus of same skeleton produced corrected age $2620 \pm 70\left(\delta^{13} \mathrm{C}=-14.3 \%\right.$ ) and a second skeleton (left femur) in same multiple burial produced corrected age $2660 \pm 260$ $\left(\delta^{13} \mathrm{C}=-16.9 \%\right.$ c $)($ GSC-2888 and -2886: unpub).

\section{KeNi-4 site series, Northwest Territories}

Charcoal in sand, $10.36 \mathrm{~m}$ above shoreline Whitefish Lake, SE Dist Mackenzie $\left(62^{\circ} 46^{\prime} \mathrm{N}, 106^{\circ} 58^{\prime} \mathrm{W}\right)$. Sand knob 500m long, $366 \mathrm{~m}$ asl, adjacent to caribou water crossing. Five levels and several sub-levels. Levels 1 to 4, Late Middle and Early Taltheilei tradition; Level 5, mixture of Plains and Shield Archaic. Previous dates range from $1670 \mathrm{BC}$ to $\mathrm{AD}$ 1545 (S-1261 and -1259: R, 1979, v 21, p 90). Coll 1977 by B C Gordon, J Thomsen, L Jackson, D Jackson, and M Barlow; subm 1977 by B C Gordon.

S-1434. KeNi-4 site, Level 5

$2940 \pm 210$

Charcoal in sand (NMC-950) from Area C, 0S6W, assoc with Duncan point, scrapers, biface fragments, and flakes. Plains Archaic ca 2000 BC.

S-1435. KeNi-4 site, Level 5

$4040 \pm 130$

Charcoal in sand (NMC-95l) from Area C, Sqs 2S10W, 2N10W, 0S10W, and 1N1E. Plains Archaic ca 2000 BC.

S-1436. KeNi-4 site, Level 4

Charcoal in sand (NMC-952) from Area C, 3N2E. Early Taltheilei ca $600 \mathrm{BC}$ to AD 100. 
S-1437. KeNi-4 site, Level 4

Charcoal in sand (NMC-953) from Area C, 2N1E and 1N1E. Early Taltheilei ca 600 BC to AD 200.

S-1438. KeNi-4 site, Level 4

$1550 \pm 60$

Charcoal in sand (NMC-954) from Area C, 0N4W. Early Taltheilei ca $600 \mathrm{BC}$ to $\mathrm{AD} 200$.

S-1440. KeNi-4 site, Level 4

$2480 \pm 60$

Charcoal in sand (NMC-956) from Area C, 2S4-6W, 2S6W. Early Taltheilei ca $600 \mathrm{BC}$ to AD 200.

S-1441. KeNi-4 site, Level 2

$1040 \pm 70$

Charcoal in sand (NMC-957) from Area C, 0N4W. Ca 500 to $1000 \mathrm{yr}$.

S-1529. KeNi-4 site, Level 1

Charcoal in sand (NMC-976) from Area $A, 2 S 4$ Taltheilei, only a few centuries old.

S-1530. KeNi-4 site, Level 2

$1060 \pm 60$

Charcoal in sand (NMC-977) $\mathbf{1 0 4 0} \pm \mathbf{8 0}$ 2SeW, 2S2W, 4S1W. Middle Taltheilei ca AD 400 to 1000.

\section{S-1531. KeNi-4 site, Level 3}

Charcoal in sand (NMC-978) from Area A, 1S0W, 1S1W, 2S2W. Early Taltheilei, possibly Pre-Dorset, ca 500 BC to AD 500.

General Comment (BCG): with two exceptions, all dates fall within temporal range based on point typology and stratigraphy. S-1434 and -1435 wrong as bottom level dated 1670 and 2090 BC (S-1261: R, 1979, v 21, p 90). S-1434, small sample, also included charcoal from Sub-level 4 b, falls during barrenland Pre-Dorset occupation also in site. Level 4 gives three acceptable dates; S-1428 appears late. It is unlikely that Early Taltheilei (Hennessey) points persist until Middle Taltheilei ca AD 500, considering respective temporal clusters at 500 to $100 \mathrm{BC}$ and $100 \mathrm{BC}$ to $\mathrm{AD}$ 500 in other sites. S-1441 indicates presence of small underground-stem points by Ca AD 900 at tree line. Stemmed points are present throughout Late Taltheilei Chipewyan but are outnumbered by side-notched points. S-1531 and -1530 acceptable; S-1529 appears too old.

\section{Evergreen site series, Northwest Territories}

Charcoal and calcined bone from site (KeNi-5), ca $4.6 \mathrm{~m}$ above Whitefish Lake, SE Dist MacKenzie $\left(62^{\circ} 48^{\prime} 50^{\prime \prime} \mathrm{N}, 106^{\circ} 57^{\prime} 40^{\prime \prime} \mathrm{W}\right)$. Small blowout with predominantly Taltheilei tools. Dates will correlate site with KeNi-4 site, 1.6km SE. Coll 1977 by L Jackson and C Thompson; subm 1977 by B C Gordon.

\section{S-1439. Evergreen site, Feature 1}

$1860 \pm 130$

Charcoal and calcined bone (NMC-955), numerous tools, no projectile points. 
S-1528. Evergreen site, Level $1 \mathrm{~b}$

$1350 \pm 80$

Charcoal in sand (NMC-975). Several tools found on blowout floor below wall of excavation.

General Comment (BCG): multicomponent site, four sub-levels. Tools definitively Middle Taltheilei in Sub-level 1. Feature 1 had no traceable sub-levels. Dates acceptable.

\section{S-1442. Weiser site, Ontario}

$1550 \pm 70$

Carbonized wood (NMC-933) from site (AdHo-1), Chatham, Kent Co $\left(42^{\circ} 36^{\prime} \mathrm{N}, 82^{\circ} 23^{\prime} \mathrm{W}\right)$. From Units 50 and 52, S16, in midden below sand. Middle Late Woodland/Mississippian Fort Ancient affiliation, with palisade and internal circular enclosure. Assoc with maize kernels and two large grain sheaths. Ca 1000 yr. Coll and subm 1977 by E L Kroon, Univ Windsor. Comment (ELK): carbonized remains id. as "grain-like". Quantity of maize from midden deposits suggests Weiser peoples had agriculture confirming that maize agriculture in Ontario sites antedates those in SE Michigan (Stothers, 1973). Date earlier than Mississippian but lithic assemblage fits range and ceramic traits (shell tempering, strap handles, and applique elements) compatible with other Mississippian sites and $\mathrm{N}$ to $\mathrm{S}$ influence. One of earliest "Mississippian-like" sites exhibiting characteristic Woodland base blended with minor "Mississippianisms" termed Intermediate Period AD 400 to 900 (Stoltman, 1978).

\section{S-1447. Greenwater Lake site, Saskatchewan}

$4390 \pm 110$

Bone fragments (GWL-1) from site (FcMv-1), E central Saskatchewan $\left(52^{\circ} 29^{\prime} 45^{\prime \prime} \mathrm{N}, 103^{\circ} 32^{\prime} 10^{\prime \prime} \mathrm{W}\right)$. Partially disturbed burial representing a primary interment recovered from back slope of road cut. Assoc with red ocher and Oxbow projectile point. Coll 1973 by Royal Canadian Mounted Police and E G Walker, Univ Saskatchewan; subm 1977 by I G Dyck, Saskatchewan Nat Hist Mus. Comment (EGW): date consistent with other Oxbow occupations on N Plains.

\section{Gowen site series, Saskatchewan}

Charcoal and unburned bone fragments from site (FaNq-25) on terrace of S Saskatchewan R, within city limits of Saskatoon $\left(52^{\circ} 05^{\prime} 45^{\prime \prime}\right.$ $\mathrm{N}, 106^{\circ} 42^{\prime} 20^{\prime \prime} \mathrm{W}$ ). From $480.4 \mathrm{~m}$ asl processing area, large herbivores and smaller mammals, assoc with chipped stone tools and lithic debris. Early Middle Prehistoric affiliation (Schroedl and Walker, 1978), ca 6000 yr. Coll 1977 by E G Walker and A R Schroedl; subm 1978 by E G Walker.

S-1448. Gowen site, $S$ main excavation $5760 \pm 140$

Charcoal (GOW-1) from paleosol occupation layer, $1.5 \mathrm{~m}$ depth, sterile sands above and below zone.

S-1457. Gowen site, main excavation

$6150 \pm 110$ 
S-1526. Gowen site, $W$ margin

$4730 \pm 130$

Unburned bone (NMC-990) from extreme W margin, profile showed two thin buried Soil A horizons sealed above and below by sterile sands. Lower horizon prehistoric living floor.

S-1527. Gowen site, disturbed area

$5670 \pm 140$

Unburned bone (NMC-991) recovered in salvage excavation of area disturbed by heavy equipment.

General Comment (EGW): S-1526 inconsistent and rejected as too recent.

S-1506. Lewis site, Saskatchewan

$1270 \pm 70$

Bone (NMC-981) from site (FkNc-32), S bank of Saskatchewan R, opposite Thomson I., $45 \mathrm{~km}$ downstream from Saskatchewan R forks $\left(53^{\circ} 14^{\prime} \mathrm{N}, 104^{\circ} 28^{\prime} \mathrm{W}\right)$. Mammal bone from various locations in four contiguous test pits, 24 to $55 \mathrm{~cm}$ depth. Site has 2 occupations; partially destroyed by plowing near surface and at 40 to $60 \mathrm{~cm}$ depth. Surface occupation yielded 1 Avonlea and 1 Duncan projectile point. Lower level had no diagnostic tools. Should date lower occupation. Coll 1977 by D Meyer, J Carter, J Light, and S Pattison; subm 1978 by D Meyer, Saskatchewan Research Council. Comment (DM): date could apply to either Besant or Avonlea phase occupation. Two projectile point preforms from lower level appear too robust for Avonlea; site probably component of Besant phase.

S-1522. EhPp-1 site, Alberta

$1980 \pm 90$

Bone from buried stone circle site $\mathrm{N}$ of Calgary $\left(51^{\circ} 06^{\prime} \mathrm{N}, 114^{\circ}\right.$ $\left.15^{\prime} \mathrm{W}\right)$. From Ring B, assoc with cultural material and tipi rings id. as Besant phase of Middle Prehistoric period. Coll 1977 and subm 1978 by J M Quigg. Comment (JMQ): date acceptable for assoc Besant points.

\section{Washout site series, Yukon Territory}

Charcoal and charred fat from site $(\mathrm{NjVi}-2)$, Pauline Cove, Hershel I., $\mathrm{N}$ of historic settlement along beach $\left(69^{\circ} 34^{\prime} \mathrm{N}, 138^{\circ} 48^{\prime} \mathrm{W}\right)$. Early W Thule winter house, planked driftwood construction. Extensive occupation suggested by midden accumulation, sealing primary subsistence activity, multi-family occupation (Walker-Yorga, 1979). Coll 1979 by B Yorga and R Higgins; subm by B Yorga, Univ Toronto.

S-1532. Washout site, Sq N2E3

$1570 \pm 60$

Charcoal (NMC-967) from NW quad in basal midden, outside main chamber of house. Area has evidence of extensive manufacturing activity. Ca 900 yr.

S-1533. Washout site, Sq N5E3

$990 \pm 100$

Charcoal (NMC-968) from NE quad in basal midden, adjacent to wooden dolls below house floor. Ca $900 \mathrm{yr}$. 
S-1534. Washout site, Sq N1El

$1510 \pm 90$

Charred fat (NMC-969) from NW quad in basal midden, outside main chamber, assoc with pottery lamp fragments. Ca $900 \mathrm{yr}$.

General Comment (BY): S-1533 acceptable. S-1532 and -1534 both obtained from oil-soaked deposits and may account for similarity, if 400-yr sea mammal adjustment applied dates are comparable to other Thule sites in Beaufort Sea area. Absence of Birnirk sites and early dates on Thule sites may require revision of accepted Thule chronology in W Arctic. Washout site interpreted as evidence of early W Thule occupation.

\section{Benson site series, Ontario}

Charcoal from site (BdGr-1), Bexley Twp, Victoria Co $\left(44^{\circ} 48^{\prime} \mathrm{N}\right.$, $\left.78^{\circ} 55^{\prime} \mathrm{W}\right)$. Palisaded Huron village, 1.5ha, occupied during time of initial introduction of European items into area, after destruction of St Lawrence Iroquois. Coll and subm 1977 by P Ramsden, McMaster Univ.

\section{S-1535. Benson site, House $10 \quad 430 \pm 80$} $370 \mathrm{yr}$

Charcoal (NMC-962) from Sq 215-380, Feature 5, Layer 2, ca 350 to

S-1539. Benson site, House 14

$620 \pm 70$

Charcoal (NMC-966) from Sq 295-330, Feature 2, ca 350 to $370 \mathrm{yr}$.

General Comment (PR): S-1535 acceptable. S-1539 seems much too early, with no apparent explanation.

\section{Coulter site series, Ontario}

Charcoal from site (BdGr-10), Bexley Twp, Victoria Co $\left(44^{\circ} 36^{\prime} \mathrm{N}\right.$, $\left.78^{\circ} 54^{\prime} \mathrm{W}\right)$. Palisaded Huron village, 3.5ha, occupied during time of initial introduction of European items in area, after destruction of St Lawrence Iroquois. Coll and subm 1977 by P Ramsden.

S-1536. Coulter site, Sq 310-335 $530 \pm 80$

Charcoal (NMC-963) from Sub-sq 7, Midden 62, 20 to $30 \mathrm{~cm}$ level, ca 375 to $399 \mathrm{yr}$.

S-1537. Coulter site, Sq 310-355

$800 \pm 60$

Charcoal (NMC-964) from Sub-sq 3, Stratum B, Midden 62, 20 to $30 \mathrm{~cm}$ level, ca 375 to $399 \mathrm{yr}$.

General Comment (PR): undisturbed midden deposit, unexplained discrepancy between dates of samples only a few $\mathrm{m}$ apart. S-1536 earlier than expected but later end of range acceptable for initial occupation that underwent several expansions. S-1537 far too early.

\section{S-1538. Kirche site, Ontario}

$400 \pm 80$

Charcoal (NMC-965) from site (BcGr-8), Fenelon Twp, Victoria Co $\left(44^{\circ} 30^{\prime} \mathrm{N}, 78^{\circ} 53^{\prime} \mathrm{W}\right)$. From Sq 295-300, feature 10, Layer 2, House 1. Palisaded Huron village, $1.2 \mathrm{ha}, 274 \mathrm{~m}$ asl, antedates introduction of European items into Victoria area and destruction of St Lawrence 
Iroquois. Coll and subm 1977 by P Ramsden. Comment (PR): date is acceptable. Site has produced European material and satisfactory introduction date. Marks first immigration of foreign Iroquoian groups into Trent valley, probably postdates Emerson's Hardrock site which lacks this influence.

\section{HdDe-5 site series, Quebec}

Charcoal and calcined bone on beach terrace between two interfluves of paleo-delta ca $200 \mathrm{~m}$ from present shores of Indian House Lake $\left(56^{\circ} 39^{\prime}\right.$ $\left.\mathrm{N}, 64^{\circ} 45^{\prime} \mathrm{W}\right)$. Oval to rectangular tent ring with large central depression serving several functions including hearth. Closest comparisons with Rattler's Bight complex of Maritime Archaic tradition. Coll 1976, 1977 by I Badgley, A Bergeron, and J L Pilon; subm 1978 by J L Pilon, Univ Toronto.

\section{S-1540. HdDe-5 site, Sq 0-2E} $3000 \mathrm{yr}$.

Charcoal (NMC-970) in fill of large central depression, ca 2000 to

S-1541. HdDe-5 site, Sq 0-2E

$3540 \pm 60$ to $3000 \mathrm{yr}$.

Calcined bone (NMC-971) in fill of large central depression, ca 2000

\section{S-1542. HdDe-5 site, Sqs 6N-6W, 6N-2W}

Charcoal (NMC-972) from charcoal layer immediately below humus, which covered entire site area assoc with tundra fire. Should postdate occupation of structure, ca 1000 to $2000 \mathrm{yr}$.

\section{S-1543. HdDe-5 site, central depression}

Modern

Calcined bone (NMC-973) from Sqs $8 \mathrm{~N}-2 \mathrm{~W}, 8 \mathrm{~N}-4 \mathrm{~W}, 6 \mathrm{~N}-4 \mathrm{~W}$, and $6 \mathrm{~N}-2 \mathrm{~W}$, in fill of large central depression, ca 2000 to $3000 \mathrm{yr}$.

General Comment (JLP): S-1540 and -1541 should give similar date; evidence suggests only one occupation. Typologic analogies tentatively to late manifestation of Maritime Archaic tradition. Both dates within proper time period; recent date more acceptable. S-1542 in line with dated artifact bearing buried humus (980 yr BP) obtained $4 \mathrm{~m}$ above lake level near HdDe-5 by G Samson.

\section{S-1544. Bull Frog site, New Brunswick}

$1860 \pm 70$

Charcoal (NMC-974) from site (BIDo-4), W bank, mouth of Oromocto $\mathrm{R}$, St John R valley, central New Brunswick (45 $51^{\prime} 20^{\prime \prime} \mathrm{N}, 66^{\circ} 31^{\prime} 30^{\prime \prime}$ W). From floor, Test Unit $1,55 \mathrm{~cm}$ depth. Test unit ca $1.5 \mathrm{~m}$ above high tide, ca $2 \mathrm{~m}$ inland from $\mathrm{R}$ bank with annual flooding. Hence, stratified silt and sand deposits. Historic materials in upper $20 \mathrm{~cm}$, prehistoric ceramics and flakes to $1 \mathrm{~m}$ depth. Assoc with concentration of rockerstamped dentate ceramics, ca 2000 yr. Coll 1975 by P Allen; subm 1978 by C J Turnbull, Prov Archaeol New Brunswick. Comment (CJT): date as expected. 


\section{Renard site series, Ontario}

Charcoal from site (CbHs-5), NE shore Fox I., Mississagi Delta, Cobden Twp (46 $\left.16^{\prime} 12^{\prime \prime} \mathrm{N}, 83^{\circ} 01^{\prime} 57^{\prime \prime} \mathrm{W}\right)$. Prehistoric Terminal Woodland site of Algonkian affiliation, at $183 \mathrm{~m}$ asl. Coll 1977 by $\mathrm{K}$ Sewayze and C Sénéchal; subm 1978 by K Buchanan, Laurentian Univ.

\section{S-1547. Renard site, Sq S91W25}

$430 \pm 80$

Charcoal (NMC-982) from NE corner Sq S91W25, $8 \mathrm{~cm}$ depth in B horizon, assoc with probable hearth feature. Ca AD 1300 to 1500.

\section{S-1548. Renard site, Sq N6W2}

$1060 \pm 70$

Charcoal (NMC-983) from NW corner of Sq N6W2, Level 3, 8 to $12 \mathrm{~cm}$ depth, assoc with pit feature. Ca AD 1300 to 1500.

General Comment (KB): S-1548 probably too early, as at this period, Mississagi delta was very swampy and unsuitable for occupation (Lewis, 1970). Based on pottery evidence, site was probably seasonally occupied more or less continuously from AD 1300 to 1500 .

\section{Patrick Point Rock Structure series, Ontario}

Charcoal from (CbHs-14), on land point, E bank where Mississagi

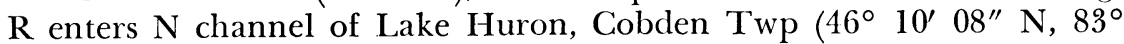
$00^{\prime} 34^{\prime \prime} \mathrm{W}$ ). Rock mound $183 \mathrm{~m}$ asl, on promontory with little assoc cultural material. Cultural deposits on beach, ca 40 to $50 \mathrm{~cm}$ depth. Algonkian affiliations. Coll 1977 by M Brizinski and K Swayze; subm 1978 by K Buchanan.

\section{S-1549. Patrick Point Rock Structure, Test Pit $1 \quad 300 \pm 60$} Charcoal (NMC-984) on beach.

\section{S-1552. Patrick Point Rock Structure, Test Pit $600 \pm 40$}

Charcoal (NMG-987), $50 \mathrm{~cm}$ depth.

General Comment (KB): no cultural material other than miniscule potsherds assoc with actual rock structure. If rock structure assoc with archaeol carbon-bearing deposit, then dates bracket structure.

\section{S-1550. Boom Camp site, Ontario $\quad 90 \pm 60$}

Charcoal (NMC-985) from site (CbHs-15), on extinct bay of Lake Huron, ca $1 \mathrm{~km} \mathrm{E}$ of Mississagi R, Cobden Twp $\left(46^{\circ} 10^{\prime} 30^{\prime \prime} \mathrm{N}, 83^{\circ} 00^{\prime}\right.$ $\left.17^{\prime \prime} \mathrm{W}\right)$. From NW corner of Sq S38W1, $15 \mathrm{~cm}$ depth, assoc with pottery concentration. Prehistoric Terminal Woodland site of Algonkian affiliation, $183 \mathrm{~m}$ asl. Ca AD 1400 to 1500 . Coll and subm 1977 by K Buchanan. Comment (KB): Huron pottery indicates site probably dates to AD 1500 to 1600 . Late date is probably late historic disturbance.

\section{S-1551. Chiblow-3 site, Ontario}

Charcoal (NMC-986) from site (CbHs-4), just $\mathrm{S}$ of railway bridge, $\mathrm{E}$ bank Mississagi R, Cobden Twp (46 $\left.16^{\circ} 11^{\prime} 37^{\prime \prime} \mathrm{N}, 83^{\circ} 01^{\prime} 44^{\prime \prime} \mathrm{W}\right)$. From Sq W8N1, $8 \mathrm{~cm}$ depth, S end of portage and fishing camp, $183 \mathrm{~m}$ asl. Protohistoric-Historic, Algonkian affiliation. Coll 1977 by M Bertulli; 
subm 1978 by K Buchanan. Comment (KB): date fits with other temporal evidence.

\section{JjL1-1c site series, Northwest Territories}

Charcoal and bone from SE shore of Oftedal Lake, Keewatin Dist $\left(61^{\circ} 38^{\prime} \mathrm{N}, 97^{\circ} 54^{\prime} \mathrm{W}\right)$. Small stratified site, $192 \mathrm{~m}$ asl with three occupations; Taltheilei (Zone 1), Arctic Small Tool tradition (Zone A) and Shield Archaic (Zone B) (Morrison, 1978). Coll and subm 1977 by D Morrison, Natl Mus Canada.

S-1553. JjL1-1c site, Zone A

$1450 \pm 50$

Charcoal (NMC-988) from hearth in Sq 4. Should date Pre-Dorset component ca $3000 \mathrm{yr}$.

\section{S-1554. JjL1-1c site, Zone B}

Calcined bone (NMC-989) from cemented sand with calcined bone floor, Sq 4, ca 3700 to $5000 \mathrm{yr}$.

General Comment (DM): dates unacceptable. Zone A at least $1300 \mathrm{yr}$ too recent, 90 BC date from same level of site (Irving, 1968) also seems incorrect for Pre-Dorset affiliation. S-1554 inconsistent with stratigraphy and Shield Archaic affiliation.

\section{S-1574. Graham site, Saskatchewan $\quad \mathbf{3 2 5 0} \pm \mathbf{5 0}$}

Bone (NMC-1011) from site (FaNq-30), S Saskatchewan valley, S of Saskatoon $\left(52^{\circ} 04^{\prime} 45^{\prime \prime} \mathrm{N}, 106^{\circ} 45^{\prime} 15^{\prime \prime} \mathrm{W}\right)$. From cremated burial, sand dune area, $10 \mathrm{~cm}$ depth. Human bone fragments, lithic, and bone artifacts assoc uncertain. Coll and subm 1977 by E G Walker, Univ Saskatchewan. Comment (EGW): single burned projectile point recovered from same hearth as human remains similar to Duncan point of late Plains Archaic. Date supportive of McKean complex affiliation and consistent with other known McKean complex region dates.

\section{S-1575. Bethune site, Saskatchewan $1390 \pm 40$}

Bison bone (NMC-1012) from site (EeNg-6) near Bethune $\left(50^{\circ} 46^{\prime}\right.$ $\left.50^{\prime \prime} \mathrm{N}, 105^{\circ} 07^{\prime} 10^{\prime \prime} \mathrm{W}\right)$. From shallow pit, stratigraphy disturbed by cultivation. Human remains assoc with faunal remains. Probable Woodland affiliation ca AD 1000. Coll 1972 by $R$ Tillie, Natl Hist Mus Saskatchewan; subm 1978 by E G Walker. Comment (EGW): in absence of diagnostic material, date considered reliable.

\section{S-1583. Crown site, Saskatchewan $\quad 1070 \pm 40$}

Burned and unburned mammal bone fragments (NMC-1010) from site (FhNa-86), S side Saskatchewan R at mouth of Creek, $9.5 \mathrm{~km}$ SW of Nipawin $\left(53^{\circ} 18^{\prime} \mathrm{N}, 104^{\circ} 09^{\prime} \mathrm{W}\right)$. From occupation level covered by $13 \mathrm{~cm}$ river sediments; probably continuously damp in river bottom clay deposits. Clearwater Lake phase site few $\mathrm{km}$ downstream in same microenvironment. Ca AD 1400 to 1600. Coll 1976 and subm 1978 by D Meyer. Comment (DM): no diagnostics recovered, too old for Clearwater Lake phase, must relate to other earlier occupation. 
S-1600. Adelaide Island-2 site, Ontario

$2340 \pm 60$

Charcoal (NMC-1008) from site (BcFx-4), E point of Adelaide I., St Lawrence R ( $44^{\circ} 26^{\prime} 15^{\prime \prime}$ N, $\left.75^{\circ} 50^{\prime} 18^{\prime \prime} \mathrm{W}\right)$. From Test Sq 2, 10 to $15 \mathrm{~cm}$ level. Multicomponent site ranging from early Point Peninsula culture to historic. Should date major level pertaining to Middle Point Peninsula culture, ca AD $200 \pm 300$. Coll and subm 1978 by J V Wright. Comment (JVW): date pertains to early Point Peninsula occupation of site. Early Point Peninsula material occurred mainly in subsequent 15 to $20 \mathrm{~cm}$ level and since superimposed probability charcoal erroneously assigned to latter occupation.

\section{S-1601. Squaw Island South site, Ontario}

$1160 \pm 70$

Charcoal (NMC-1009) from site (BcFx-5), S point of Squaw I., St Lawrence R ( $\left.44^{\circ} 24^{\prime} 55^{\prime \prime} \mathrm{N}, 75^{\circ} 52^{\prime} 45^{\prime \prime} \mathrm{W}\right)$. From Test Sq 1, hearth floor resting on $10 \mathrm{~cm}$ level in NW corner. Multicomponent site ranging from Middle Point Peninsula culture to historic. Should date Middle Point Peninsula ca AD $200 \pm 300$. Coll and subm 1978 by J V Wright. Comment (JVW): hearth and assoc charcoal apparently pertains to later occupation that rests directly upon earlier Point Peninsula material. Deposits directly superimposed responsible for assoc error of feature.

\section{Cox/Swanson site series, Nova Scotia}

Charcoal and marine shell from site (BkCq-10), $9 \mathrm{~km} \mathrm{NNW}$ of Pictou, on headbank at mouth of Caribou R, W bank $\left(45^{\circ} 45^{\prime} \mathrm{N}, 62^{\circ}\right.$ $\left.45^{\prime} \mathrm{W}\right)$. Late prehistoric shell midden at 1 to $3 \mathrm{~m}$ asl, seasonally occupied. Probably ancestral Micmac. Ceramics similar to other late sites in Maritimes from AD 900 to 1400 . Coll and subm 1978 by D L Keenlyside, Natl Mus Canada.

\section{S-1602. Cox/Swanson site, Test Pit 2}

$1420 \pm 70$

Charcoal (NMC-1013) from Level 4, 22 to $24 \mathrm{~cm}$ depth.

\section{S-1603. Cox/Swanson site, Test Pit 3}

Charcoal (NMC-1014) from central hearth area, $54 \mathrm{~cm}$ depth.

\section{S-1604. Cox/Swanson site, Test Pit 3}

$\mathbf{7 0 0} \pm \mathbf{4 5}$

Marine shell (NMC-1015) from Level 2, 40 to $42 \mathrm{~cm}$ below surface.

General Comment (DLK): other dated shell midden sites in Nova Scotia and New Brunswick with similar cord-marked ceramics and lithics generally ca AD 900 to 1400 period. S-1603 acceptable for site. S-1602 probably too early according to typologic comparisons. S-1604 acceptable comparison within error to charcoal date.

\section{Oxbow site series, New Brunswick}

Charcoal from site (CfDl-1), on 1 to $2 \mathrm{~m}$ terrace, $\mathrm{N}$ side of Little Southwest Miramichi R, above Red Bank Community, Red Bank Indian Reserve $\left(46^{\circ} 57^{\prime} 25^{\prime \prime} \mathrm{N}, 65^{\circ} 51^{\prime} 30^{\prime \prime} \mathrm{W}\right)$. Site culturally stratified by layers of sands and silt to over $2 \mathrm{~m}$ depth. Majority of cultural deposits appear to lie within period of ceramic occupations. Coll 1978 by P Levi, A 
Emin, and A Ferguson; subm 1978 by D L Keenlyside for P Allen, Hist Research, Fredericton.

S-1605. Oxbow site, Unit 78-11

$2640 \pm 50$

Charcoal (NMC-1016) assoc with elongated hearth area and small expanding stemmed projectile point.

\section{S-1606. Oxbow site, Unit 78-12}

$2150 \pm 70$

Charcoal (NMC-1017) assoc with bi-pointed quartz projectile point.

S-1607. Oxbow site, Unit 78-11

$1680 \pm 50$

Charcoal (NMC-1018) assoc with charcoal-stained pit connected to area containing slightly contracting stemmed projectile point.

General Comment (PA): dates combined with other Oxbow dates and stratigraphy contribute to $3000-y r$ projectile point chronology of site and region of New Brunswick. S-1605 and -1653 at 2600 \pm 60 вP (unpub) directly assoc with dentate stamp, pseudo-scallop shell and plain surface pottery. Lowest levels of site, below straight-stemmed Archaic-like points still produced dentate stamped pottery. S-1607 recovered below cordwrapped stick-decorated ware but assoc with organically tempered plain sherds; date just prior to similar ceramic assoc for Savoie site (S-713: R, 1975, v 17, p 328). S-1607 also assoc with circular house structure.

\section{S-1631. Tschetter site, Saskatchewan}

$920 \pm 45$

Bison bone (NMC-1035) from site (FbNr-1), E edge of Dunfermline sand hills $\left(52^{\circ} 12^{\prime} 50^{\prime \prime} \mathrm{N}, 106^{\circ} 55^{\prime} 52^{\prime \prime} \mathrm{W}\right)$. From FbNr-1-81, Level 3, 40 to $50 \mathrm{~cm}$ below datum. Communal bison kill site, $506 \mathrm{~m}$ asl, probably corral or pound. Dated to Late Prehistoric period with Prairie sidenotched points. Will date major bone-bed layer and supports previous date of AD $945 \pm 75$ (S-669: R, 1975, v 17, p 342). Coll 1976 and subm 1979 by U Linnamae, Univ Saskatchewan. Comment (UL): confirms previous date, acceptable for cultural horizon.

\section{S-1637. QjLd-21 site, Northwest Territories $\quad 2210 \pm 120$}

Muskox bone (NMC-1022) from Karluk I., Dist Franklin $\left(75^{\circ} 30^{\prime} \mathrm{N}\right.$, $97^{\circ} 16^{\prime} \mathrm{W}$ ). From Loc 6,11 to $12 \mathrm{~m}$ asl, possibly early Dorset, ca 800 to 400 BC. Coll and subm 1978 by J W Helmer, Univ Calgary. Comment (JWH): comparable to Level I date of Tyara site (Taylor, 1968) and several dates from T-1 and T-3 (Collins, 1956a; 1956b; 1957). S-1673 expected to be earlier than Ballantine site of $2220 \pm 140$ вP and $2450 \pm$ 220 вр (GSC-640 and GSC-658: R, 1969, v 11, p 39). Comparable dates.

\section{Melhagen site series, Saskatchewan}

Buffalo bone from site $(\mathrm{EgNn}-1), 19.3 \mathrm{~km} \mathrm{E}$ of Elbow $\left(51^{\circ} 04^{\prime} \mathrm{N}\right.$, $106^{\circ} 20^{\prime} \mathrm{W}$ ). Buffalo kill and butchering site consisting of four large bone beds. Sonota complex, previously dated $10 \pm 90$ вС (S-491: R, 1973, v 15, p 204). Coll 1971 by D Robinson and T S Phenix; subm 1979 by T S Phenix, Saskatchewan Archaeol Soc, Saskatoon. 
S-1640. Melhagen site, Sq 5E5S

$1910 \pm 70$

Buffalo bone (NMC-1036) from Bed 4 single bone layer.

S-1641. Melhagen site, Sq 100W65N

$1710 \pm 40$

Buffalo bone (NMC-1037) from Bed 3.

General Comment (TSP): on basis of proximity, four bone beds and level believed to be contemporaneous. S-1640 close to previous Bed 1 date. Assoc point type originally thought to be Besant, now assigned to Sonota complex.

\section{Port Refuge site series, Northwest Territories}

Bone from site (RbJu-1), on beach ridges at 22 to $24 \mathrm{~m}$ asl, $\mathrm{N}$ end of Port Refuge, Devon I., Dist Franklin $\left(76^{\circ} 19^{\prime} \mathrm{N}, 94^{\circ} 38^{\prime} \mathrm{W}\right)$. Cold Component consists of 31 features, many dwelling structure remains; artifacts suggest affiliations with Independence I variant of Arctic Small Tool tradition. Gull Cliff Component consists of 36 features, many appear to be dwelling remains, artifacts suggest affiliation with Pre-Dorset variant of Arctic Small Tool tradition (McGhee, 1979). Coll 1972, 1977, and subm 1979 by R McGhee.

\section{S-1660. Port Refuge site, Cold component $\quad 4450 \pm 60$}

Phoca hispida long bones (NMC-1025) from midden area S of Feature 19 on $24 \mathrm{~m}$ beach, on and in limestone gravel, 0 to $10 \mathrm{~cm}$ below surface, under sparse Saxifraga cover. Bones derive from Feature 19. Ca 3500 to $4000 \mathrm{yr}$.

S-1661. Port Refuge site, Gull Cliff component $3430 \pm 60$

Phoca hispida long bones (NMC-1026) from midden extending $\mathbf{E}$ of Feature 9, on and in limestone gravel, 0 to $15 \mathrm{~cm}$ depth, under dense Saxifraga cover. Bones derive from Feature 9. Ca 3400 to $3700 \mathrm{yr}$.

\section{S-1662. Port Refuge, Gull Cliff component $\quad 3790 \pm 60$}

Phoca hispida long bones (NMC-1027) from midden extending E of Feature 9, on and in limestone, 0 to $15 \mathrm{~cm}$ depth, under dense Saxifraga cover. Bones derive from Feature 9. Ca 3400 to $3700 \mathrm{yr}$.

\section{S-1689. Port Refuge, Cold component}

$2070 \pm 50$

Phoca hispida long bones (NMC-1024) from midden area S of Feature 19 on $24 \mathrm{~m}$ beach, on and in limestone gravel, 0 to $10 \mathrm{~cm}$ below surface, under sparse Saxifraga cover. Bones derive from Feature 19. Ca 3500 to $4000 \mathrm{yr}$.

General Comment (RM): recent radiocarbon dates on seal and whale bones from nearby Thule site at Porden Point suggest local reservoir effect up to +700 yr on marine material from Grinnell Peninsula area. If correct, then all dates except $\mathrm{S}-1660$ are more recent than expected. S-1661 and -1662 are single sample split, as well as S-1660 and -1689; differences greater than $3 \sigma$ must be pretreatment error. 


\section{S-1674. QjLd-22 site, Northwest Territories}

$3000 \pm 70$

Burned driftwood (NMC-1023) from Karluk I., Dist Franklin $\left(75^{\circ}\right.$ $\left.30^{\prime} \mathrm{N}, 97^{\circ} 16^{\prime} \mathrm{W}\right)$. From Loc 1,8 to $9 \mathrm{~m}$ asl, interior of structure, hearth within oval stone outline, ca 0 to $5 \mathrm{~cm}$ below surface. Possibly early Dorset ca 800 to 400 BC. Coll and subm 1978 by J W Helmer. Comment $(\mathrm{JWH})$ : date is too early. Typologic considerations and site elev suggest more recent occupation than adjacent QjLd-21 Loc 6 (S-1637) of $2205 \pm$ 120 BP. Probably relates to driftwood and not structure.

\section{S-1723. DcGt-2 site, Quebec}

$620 \pm 45$

Charcoal (NMC-1071) from W region of Lake Duparquet on $9 \mathrm{~m}$ escarpment, Abitibi area $\left(49^{\circ} 29^{\prime} 15^{\prime \prime} \mathrm{N}, 79^{\circ} 16^{\prime} 50^{\prime \prime} \mathrm{W}\right)$. Lake ca $274 \mathrm{~m}$ asl. From Pit Nl ca $30 \mathrm{~cm}$ below surface in depression consisting of charcoal layers and sand with flakes. Trees on site were cut, trunks left in place; ground surface irregular because of tree roots. Forest humus ca 8 to $10 \mathrm{~cm}$ thick covered with fine sand layer containing prehistoric material. Cultural affiliation undetermined. Coll 1977 by P Gauthier; subm 1979 by R Marois. Comment (RM): absence of ceramics and site location suggest much earlier occupation.

\section{S-1724. Tyendinaga Indian Reserve, Ontario}

$400 \pm 35$

Wood (Pinus strobus L) (NMC-1072) from Deseronto (44 $12^{\prime} 25^{\prime \prime}$ $\left.\mathrm{N}, 77^{\circ} 08^{\prime} 10^{\prime \prime} \mathrm{W}\right)$. From apparent prehistoric dugout canoe recovered from bog. Reserve presently Mohawk Indian but in perhistoric period it was Huron terr. Coll 1979 by C Hett and C McCauley, Canadian Conservation Inst; subm 1979 by G F MacDonald, Natl Mus Canada. Comment (GFM): since date fits $400 \mathrm{yr}$, estimate may indicate that form, material, and related features can provide approx age of canoe as they usually are found out of stratigraphy or other dateable context. Efforts to date dugout canoes in Florida, Scandinavia, Japan, Switzerland, and USSR indicate specimens are up to $8000 \mathrm{yr}$ old, but they have changed little in form almost to present in same areas. Date is part of ongoing series in E Canada.

\section{REFERENCES}

Braddell, D, Minty, C, and Tamplin, M, 1970, A prehistoric burial site neai Reston, Manitoba in W M Hlady, ed, Ten thousand years of archacology in Manitoba: Winnipeg, Manitoba Archaeol Soc, p 191-208.

Brumley, J H, 1975, The Cactus Flower site in southeastern Alberta: 1972-1974 excavations: Natl Mus Canada Mercury ser, Archaeol Survey Canada paper no. 46.

Capes, K H, 1977, Archacological investigations of the Millard Creek site, Vancouver Island, British Columbia: Syesis, v 10, p 57-84.

Clark, D W, 1977, Hahanudan Lake: an Ipiutak-related occupation of western interior Alaska: Natl Mus Canada Mercury ser, Archaeol Survey Canada paper no. 71.

1979, Ocean Bay: an early north Pacific maritime culture: Natl Mus Canada Mercury ser, Archaeol Survey Canada paper no. 86.

Collins, H B, 1956a, Archaeological investigations on Southampton and Coats Islands, NWT: Natl Mus Canada Bull 142, p 82-113. 1956b, The T-1 site at Native Point, NWT: Univ Alaska, Anthropol
Papers, v 4, no. 2, p 63-89.

NWT: Natl Mus Canada Bull 147, p 22-61.

Delibrias, G, Guillier, M T, and Labeyrie, J, 1974, Gif natural radiocarbon measurements VIII: Radiocarbon, v 16, p 15-94. 
Forbis, R G, 1968, Fletcher: A Palco-Indian site in Alberta: Am Antiquity, v 33, no. 1.

Gibson, T H, 1976, The Cherry Point site: A multicomponent lake-prairie habitation on the north-eastern plains: Western Canadian Jour Anthropol, v 6, no. 4, p 62-102.

Gilot, E, 1971, Louvain natural radiocarbon measurements X: Radiocarbon, $v$ 13, p 45-51.

Haug, J K, 1976, The 1974-75 excavations at the Cherry Point site (DkMe-10): A stratified Archaic site in southwest Manitoba: Winnipeg, Dept Tourism and Cultural Affairs, Papers in Manitoba Archaeol, final rept no. 1.

Hearne, Samuel, 1911, A journey from Prince of Wales Fort in Hudson's Bay to the Northern Ocean: Champlain Soc, Toronto.

Irving, W, 1968, The Barren Grounds in C S Beals, ed, Sciences, history and Hudson Bay: Ottawa, Dept Energy, Mines and Resources.

Kigoshi, K, Suzuki, N, and Fukatsu, H, 1973, Gakushuin natural radiocarbon measurements VIII: Radiocarbon, v 15, p 57.

King, D R, 1961, The Bracken Cairn: The Blue Jay, v 19, no. 1, p 45-53.

Lewis, C F M, 1970, Recent uplift of Manitoulin Island, Ontario: Canadian Jour Earth Sci, v 7, no. 2, p 665-676.

Long, Austin and Tamplin, M, 1977, University of Arizona dates from archaeological sites in Manitoba: Winnipeg, Dept Tourism and Cultural Affairs, Papers in Manitoba Archaeol, misc papers no. 4.

Longin, R, 1971, New method of collagen extraction for radiocarbon dating: Nature, v 230, p 241-242.

Lowdon, J A, Wilmeth, R, and Blake, W, Jr, 1969, Geological Survey of Canada radiocarbon dates VIII: Radiocarbon, v 11, p 22-42.

MacDonald, G F, 1969, Preliminary culture sequences from the Coast Tsimshian area, British Columbia: Northwest Anthropol Research Notes, v 3, no. 2, p 240-254.

MacNeish, R S, 1954, The Pointed Mountain site near Fort Liard, Northwest Territories, Canada: Am Antiquity, v 19, no. 3, p 234-253.

1955, Two archaeological sites on Great Bear Lake, NWT: Natl Mus Canada Bull 136, p 54-84.

McCallum, K J and Dyck, W, 1960, University of Saskatchewan radiocarbon dates II: Radiocarbon, v 2, p 73-81.

McGhee, R, 1979, The Paleo-Eskimo occupations at Port Refuge, high Arctic Canada: Natl Mus Canada Mercury ser, Archaeol Survey Canada paper no. 92.

McGhee, $R$ and Tuck, J A, 1976, Un-dating the Canadian Arctic: castern arctic prehistory in M S Maxwell, ed, Paleo-Eskimo problems, Soc Am Archacol Mem, no. 31 .

Mitchell, B M, Craft, D A, Butler, P, and Cawthorn, R, 1970, The Petawawa small sites report: Ontario Archaeol pub no. 15, p 20-53.

Morlan, R E, 1973, The later prehistory of the Middle Porcupine drainage, northern Yukon Territory: Natl Mus Canada Mercury ser, Archaeol Survey Canada paper no. 11.

Morrison, D, 1978, Report on an archaeological survey of the Henik Lakes, District of Keewatin, NWT (1977): Natl Mus Canada, Archaeol Survey Canada archives no. 1262.

Quigg, J M, 1976, A note on the Fletcher site: Edmonton, Archaeol Survey Alberta, occasional paper no. 1 .

1977, 1976 field investigations in the Neutral Hills regions: Edmonton, Archaeol Survey Alberta, occassional paper no. 4.

1978, Evaluation of EgPt-6: Edmonton, Archaeol Survey Alberta, occasional paper no. 5 .

Reeves, B O K, ms, 1970, Cultural change in the Northern Plains 1000 BC to AD 1000: PhD thesis, Univ Calgary.

Reger, D R, 1977, An Eskimo site near Kenai, Alaska: Univ Alaska, Anthropol Papers, v 18 , no. 2 , p $37-52$.

Rutherford, A A, Wittenberg, J, and McCallum, K J, 1973, University of Saskatchewan radiocarbon dates VI: Radiocarbon, v 15, p 193-211.

v 17, 1975, University of Saskatchewan radiocarbon dates VI [sic]: Radiocarbon,

Rutherford, A A, Wittenberg, J, and Wilmeth, R, 1979, University of Saskatchewan radiocarbon dates VIII: Radiocarbon, v 21, p 48-94.

Schroedl, A R and Walker, E G, 1978, A preliminary report on the Gowen site: an early Middle Prehistoric site on the Northwest Plains: Napao, v 8, p 1-5. 
Stoltman, J B, 1978, Temporal models in prehistory: an example from eastern North America: Current Anthropol, v 19, no. 4, p 703-746.

Stothers, D M, 1973, Early evidence of agriculture in the Great Lakes: Canadian Archaeol Assoc Bull no. 5, p 61-76.

Syms, E L, 1971, Archaeological research in southwestern Manitoba during 1970: Ottawa, Natl Mus Canada, prelim rept on file.

1972, The 1971 field season in southwestern Manitoba research area: Ottawa, Natl Mus Canada, rept on file.

ms, 1976a, Indigenous ceramics and ecological dynamics of southwestern Manitoba 500 BC-AD 1800: PhD thesis, Univ Alberta, Edmonton.

1976b, Radiocarbon dates from the Stott site (D1Ma-1), Manitoba: Archae. Facts, v 4, no. 2, p 28-33.

1977, Cultural ecology and ecological dynamics of the ceramic period in southwestern Manitoba: Plains Anthropologist, mem 12.

1978, The Devils Lake-Sourisford burial complex on the northeastern plains: Plains Anthropologist, v 24, no. 86, p 283-308.

1979, The Snyder Dam site (DhMg-37), southwestern Manitoba: Two new ceramic components: Canadian Jour Archaeol, v 3, p 41-67.

Taylor, W E Jr, 1968, The Arnapik and Tyara sites, an archaeological study of Dorset culture origins: Soc Am Archaeol, mem 22.

Tisdale, M A, 1978, Investigations at the Stott site: A review of research from 1947 to 1977: Winnipeg, Dept Tourism and Cultural Affairs, Papers in Manitoba archaeol, final rept no. 5 .

Walker-Yorga, B W D, ms, 1979, Washout: a western Thule site on Herschel Island, Yukon Territory: MA thesis, Univ Toronto.

Wheat, J B, 1972, The Olsen-Chubbuck site: A Paleo-Indian bison kill: Soc Am Archaeol, mem 26

Wilmeth, Roscoe, 1978, Anahim Lake archaeology and the early historic Chilcotin Indians: Natl Mus Canada, Archaeol Survey Canada paper no. 82.

Workman, W B, 1977, New data on the radiocarbon chronology of the Kachemak Bay sequence: Univ Alaska, Anthropol Papers, v 18, no. 2, p 31-36. 